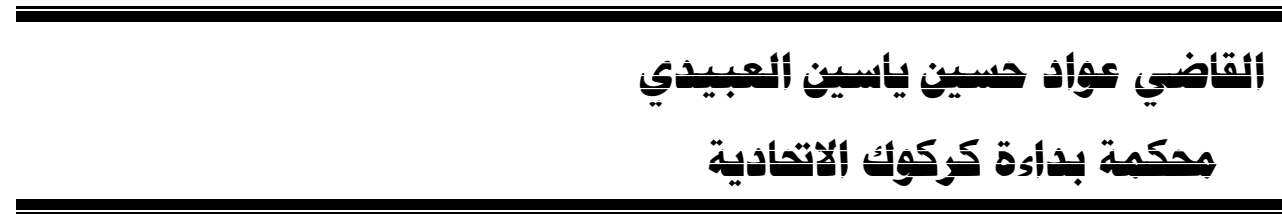

|

يحتل موضوع ((الحكم القضائي الباطل)) أهمية خاصة في العمل القضائي. تتجلى مـذه الأهميـة بغيـاب نظريـة واضحة ودقيقة عن بطلان الحكم القضائي الباطل في قـانون المرافعـات المدنيـة العراقي، وعـدم وجـود تقـنين موحد ومتجانس يتناول حالات بطلان الحكم القضـائي، وتحديد درجـة بطلانـه و ويحث آليـات تصحيح الأحكام القضـائية وتحجيم أثر بطلان الحكم القضائي على حقوق الأفراد، والسعي إلى حصر بطلان الأحكام القضائية في أضيق نطـاق، والتوسع في تصحيح الأحكام الباطلة بالاتكاء على الغايـات المرجـوة مـن الأحكام القضـائية في إنصـاف المظلـومين وإحقاق الحق، وتحقيق العدالة.ويث الثقة في القضاء، وخلق الطمأنينة بين الأفراد واستقرار العمل القضائي.

\title{
Abstract
}

The topic "Null Judicial Judgement" occupies special importance in judicial work. Such importance is expressed by absence of an accurate and clear theory regarding the nullity of a null judicial judgement in the Iraqi civil procedure law and nonexistence of homogeneous and unified codification dealing with cases of judicial judgement nullity ,determining the degree of its nullity, researching the mechanisms of correcting judicial judgements, minimizing the effect of judicial judgement nullity on individuals, rights, seeking to narrow largely judicial judgements nullity, and expanding the rectification of null judgements by relying on the ends desired from judicial judge meant sin doing justice to the victims of injustice, enforcing rights, attaining justice, restoring confidence in judicial authorities, creating tranquility among individuals and making judicial work stable.

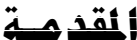

أسهم القضاء في مسيرته الطويلة في بناء محطات عظيمة بثت صـوراً مشـرفة للعدالـة القضـائية، ونـأى بها عن الأفكار الفلسفية المحضة للعدالة، مبتعدا عن صراع الأفكار المحتدم الذي اعتلى قمـم الأبـراج للمـذاهب الفكريـة الذي أبى أن يهبط إلى واقع الحياة العملية، فأفصح القضاء عن فلسفته الخاصـة في العدالـة، ورَســ طريقتها المثلىى، الـتي نبعت من خضم المعاناة الإنسانية، وامتزجت في إفرازات الحياة الواقعية، بعد تجريد العدالة من هالتها الفلسفية التي لا تقدم ولا تؤخر، واستلهم جومر العدالـة لإعـادة نشـرها في المجتمـع بخلق الفرص المتسـاوية للخصـوم في التقاضـي، وتقديس حق التقاضي، وسلوك قواعد القضاء المعروفة، والمألوفة لحسم الدعاوى وربطها بأحكام قضائية عادلة. إن فطرة البشر مجبولة على النقص والقصور ولا يمكن الادعاء بالكمال، وإذ أن القضاة هم بشر وتجنبهم للخطـأ. في العمل أمر شبه محال، فلابد من أن تأتي أحكام القضاء على هذا ليتهر المنوال.

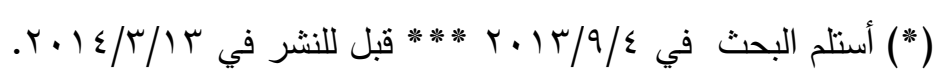


ويناء على ما تقدم فان الأحكام القضائية في أحيان كثيرة تصدر ويعتريها الخلل، أو يشويها زلل قد يمس كيـان

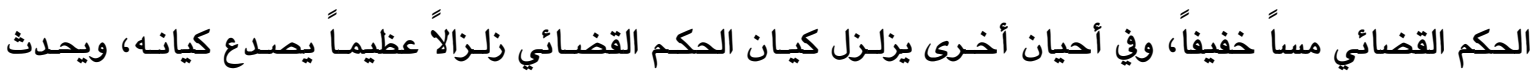
تصدعاً في بنيانه، ويكشف مواطن بطلانه -فما هو تأثير بطلان الحكم القضائي على حقوق الأفراد؟

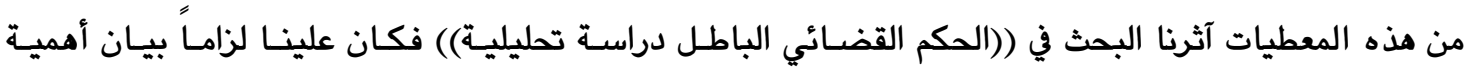
الموضوع، وهدف الدراسة والمشكلة التي تعالجها ومنهجيتها وهيكليتها (خطة البحث) وهذا ما سنتناوله تباعاً:

$$
\text { أولاً - أممية الموضوع: ومدف الراسة والمباع }
$$

يحتل موضوع ((الحكم القضائي الباطل)) أهمية خاصة في العمل القضـائي .تتجلى مـذه الأهميـة بغيـاب نظريـة واضحة ودقيقة عن بطلان الحكم القضائي الباطل في قـانون المرافعـات المدنيـة العراقي، وعـدم وجـود تقــين موحـد ومتجانس يتناول حالات بطلان الحكم القضـائي، وتحديـد درجـة بطلانـه ويحث آليـات تصديح الأحكام القضـائية

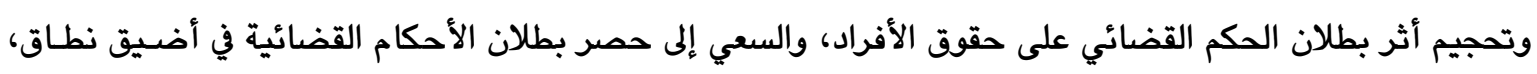

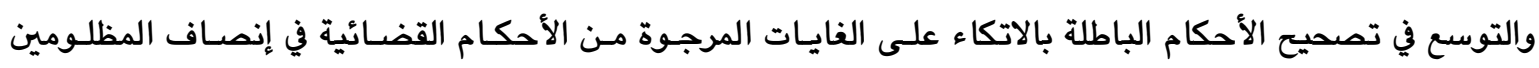
وإحقاق الحق، وتحقيق العدالة.ويث الثقة في القضاء، وخلق الطمأنينة بين الأفراد واستقرار العمل القضائي. ثانياً - مدف الدراسة:

تهدف هذه الدراسة محاولة بسيطة إلى تشخيص حالات بطـلان الحكم القضـائي، وتكشـف عـن أسباب بطلان

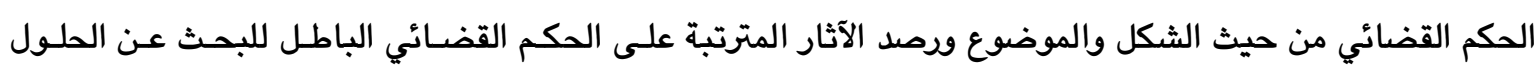
العملية، العاجلة والعادلة بإتباع الموضوعية العلمية، وتشخيص موضع الخلـل. بمـا يضـمن حقوق الأفـراد، ويحـافظ على هيبة القضاء، ويعمل على إيجاد ثوابت وأسس صحيحة لاستقرار العمل القضائي. ثالثا" - مشكلة الدراسة: لابد أن يكون الحكم القضائي السليم خاليا" من العيوب صـيحاً في شـكله ومضـمونه فـإذا مـا اعترى الحكم

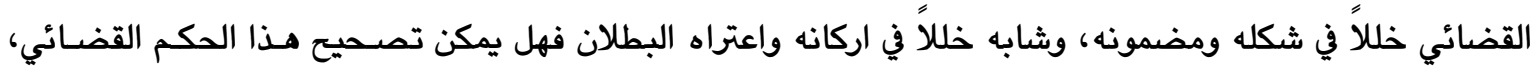

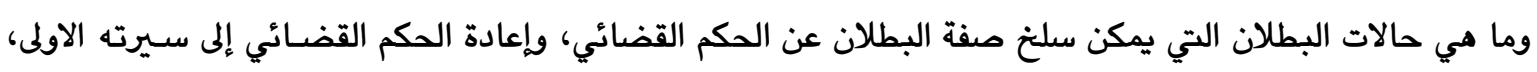

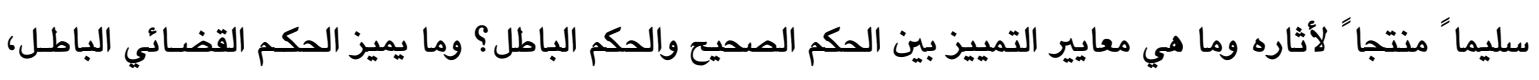

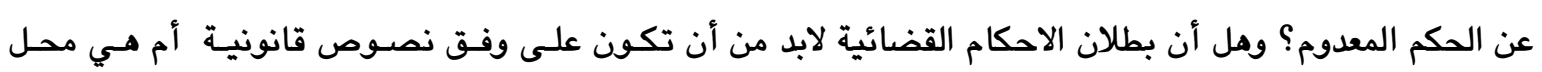
اجتهاد للقضاء؟ رابعاً - منهجية الدراسة:

للإجابة على فرضيات البحث ثم الاستعانة بـالمنهج التحليلي للوصـول إلى صـحة الفرضـيات المعتمدة في مـذهـ

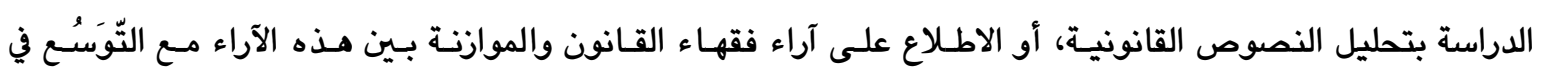

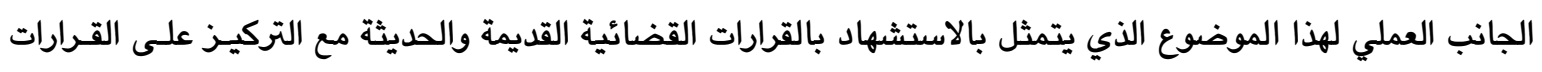
الحديثة لإغناء الدراسة المعاصرة بالنصوص القانونية والأحكام القضائية. خامسا'- ميكلية البحث ((خطة البحث)). لقد تناولنا هذه الدراسة على وفق خطة بحث تتكون من مقدمة ومبحثين وخاتمة لأهم النتائج والتوصيات وعلى وفق الآتي : (20 - n 


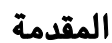

المبحث الأمل / مامية الحكم القضائي الباطل

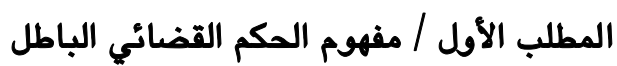

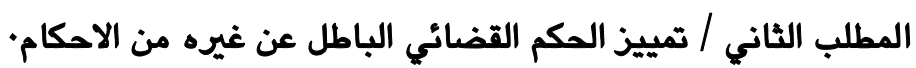

المطلب الثالث / أسباب بطلان الدكم القضائي.

المبحث الثاني / ثروط التمسك ببطلان الحكم القضائي وصوره وآثاره .

المطلب الأول / شعرط التمسك ببطلان الحكم القضائي.

المطلب الثاني / صود التمسك ببطلان الصكم القضائي.

المطلب الثالث / الأثار المترتبة على بطلان الحكم القضائي.

الخاتمة والتوصيات

المصادر

\section{الببحث الأولول}

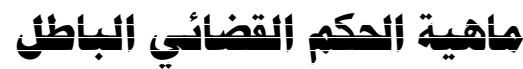

قبل الخوض في بيان ماهية الحكم القضائي الباطل لا بد من التطـرق إلى مفهوم الحكم وتميـيـه عـن غـيره مـن الأحكام.لذا سنتناول هذا البحث في ثلاثة مطالب نخص المطلب الأول لمفهوم الحكم الباطل، ونخص المطلب الثـاني لتمييز الحكم الباطل عن غيره من الاحكام، ونخص المطلب الثالث لأسباب بطلان الحكم القضائي.

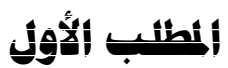

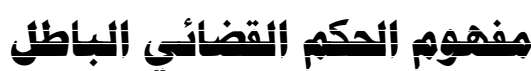

سنتناول مفهوم الحكم الباطل بتعريف الحكم الباطل في اللغة وفي الاصـطلاح الشـرعي وتعريـف الحكم الباطـل في الفقه القانوني·

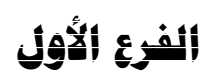

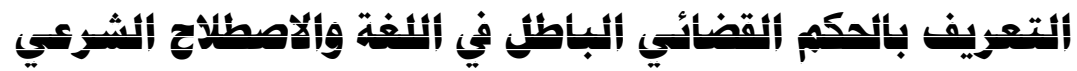

للتعريف بالحكم لابد من نتناول تعريفه في اللغة وفي الاصـطلاح الشـرعي وفي الفقهـ القـانوني وهــا مـا سـنتناوله

الحكم لغة : المنع يقال : حكم أصله : منع منعاً لإصلاح، والحكم بالشيء: أن تقضي به كذا، سواءً ألزمت ذلك

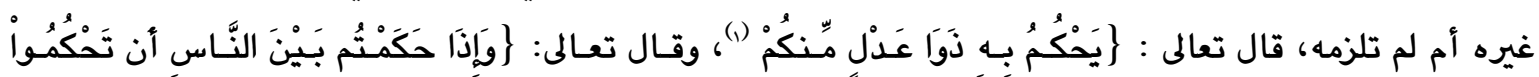

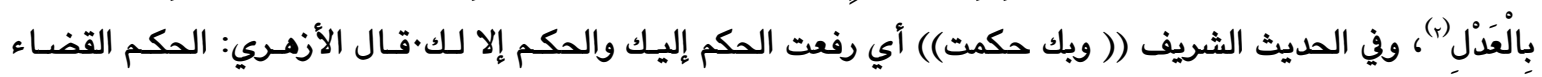
بالعدل، واحتكم فلان في مال فلان إذا جاء فيه حكمه ·والمحاكمة : المخاصمة إلى الحاكم، والحاكم منفذ الحكم والجمع

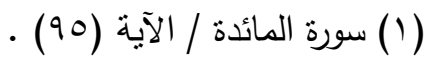

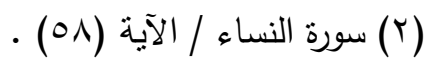


حكام، واحتكموا إلى الحاكم وتحاكموا بمعنى، والحكم مصدر قولك : حكم بيـهم بحكم أي قضى وحكم لـه وحكم البطلان في اللغة :

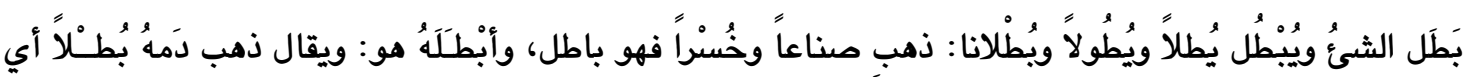

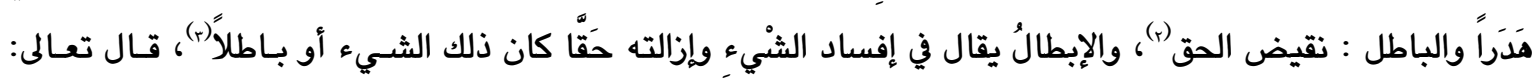

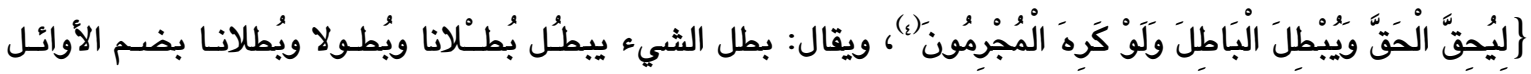

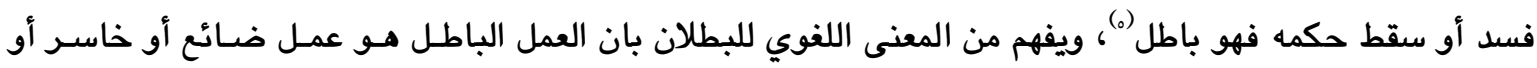
عديم القيمة، والبطلان لغة الفساد وسقوط الحكم. ويُعرّف الحكم الباطل في الفقه الإسلامي بأنه (( الحكم الذي يصـدره القاضـي الجاهـل الـذي لا يسـتند إلى علـم

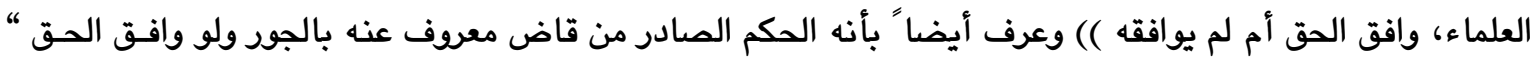
إذ يسقط الجور عدالة القاضي فيصبح القاضي غير صالح لمزاولة وظيفته “ لأن العدالة من شروط تولي القضاء معروف). الحكم القضائي في الاصطلاح الشرعي: عُرف الحكم القضائي بأنه (( هو الفعل الذي يصدر عن القاضي ومن في حكمه بطريق الإلزام لفصل الخصومة ))

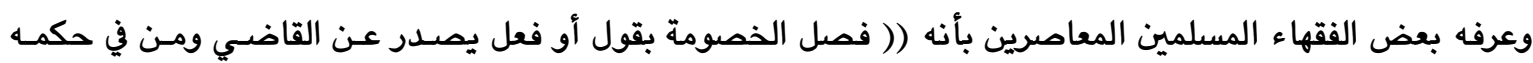

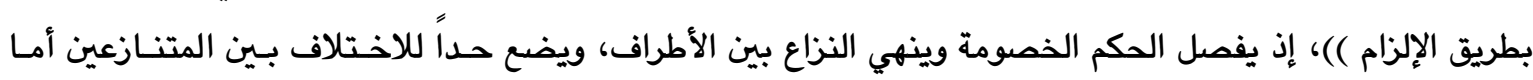

(1) ينظر : أبو الفضل جمال الدين محمد بن مكرم بن منظور الإفريقي المصري، لسان العرب، دار صـادر للطباعة

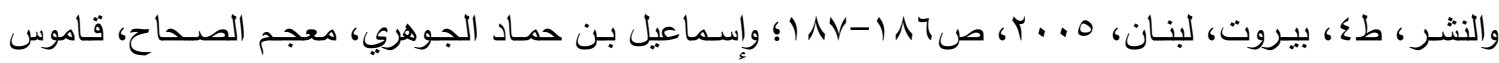

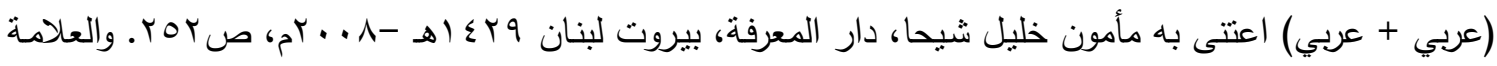
الراغب الأصفهاني، مفردات ألفاظ القران الكريم، تحقيق صفوان عدنان داودي، منشورات مطبعة النور ، قم، إيران، . r

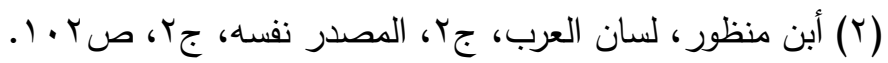

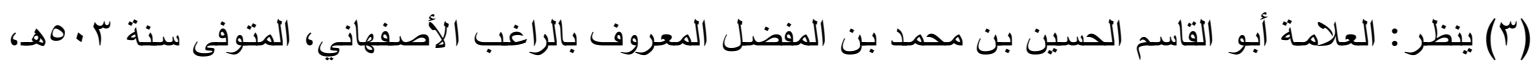
معجم مفردات ألفاظ القرآن، طس، ضبطه وصححه وخرج آياته وشواهده، إبراهيم شمس الدين، دار الكتب العلمية،

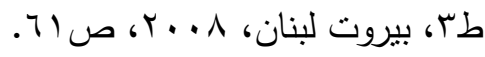

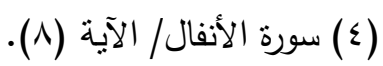

(0) ينظر : أحمد بن محمد بن علي الفيّومي المقري، المصباح المنير ، معجم (عربي - عربي) دار الحديث، القاهر

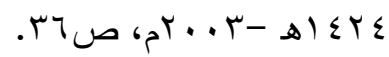

(7) ينظر : العلامة برهان الدين أبو الوفاء إبراهيم شمس الدين بن محمد بن فرحونى اليعمري المالكي تبصرة الحكام

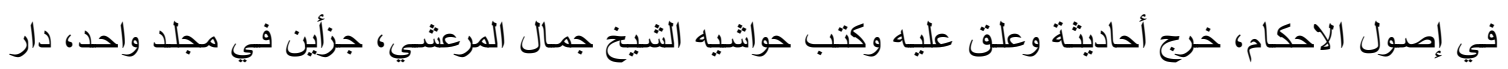

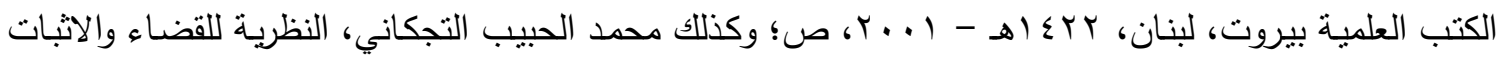
في الشريعة الاسـلامية مقارنـات بالقانون الوضعي، دار النشر المغربية، دار الثؤون الثقافية العامـة (آفاق عربيـة)

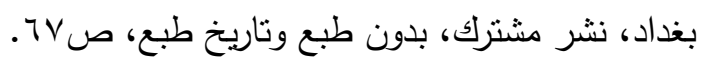


بقول أو بفعل (1)، وإن كانت منـاك تعريفـات عديدة للحكم ذكرهـا الفقهاء المسـلمون إلا أن تلـك التعريفـات تتفق في المعنى وتختلف بالعبارة)(r).

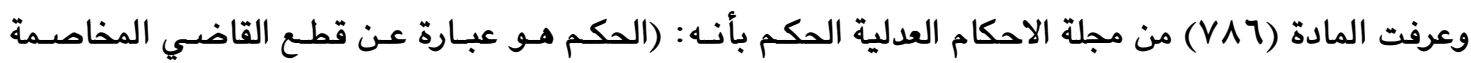
وحسمه إياما وهو على قسمين·القسم الأول: هو إلزام القاضي المحكوم به على المحكوم عليه بكلام كقولـه : حكمـت

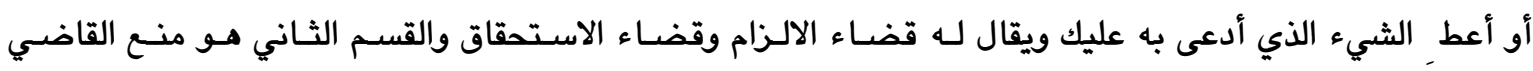
المدعي عن المنازعة بكلام كقوله : ليس لك حق أو أنت ممنوع عن المنازعة ويقال لهذا قضاء الترك).

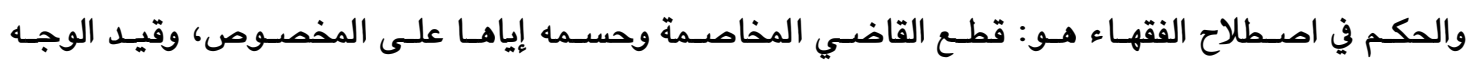
المخصوص هو لإخراج الصلح الذي يجري بين الخصمين (r). إن التعريف الأقرب إلى حقيقة ماهية الحكم هو الذي يعرف الحكم القضائي بأنه ((فصل الخصومة بقول أو بفعل ئل يصدر عن القاضي ومن في حكمه بطريق الالزام فالقول بان ((فصل الخصومة)) بيان لحقيقة الحكم فهو الحل الذي بـ إني

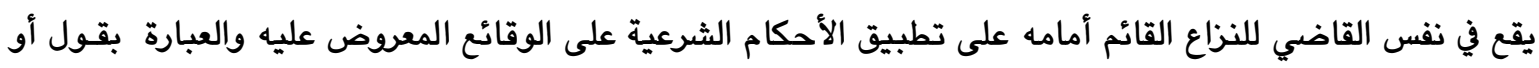
بفعل، لبيان الوسائل الدالة على الحكم، والقول بأنه ((يصدر عن القاضي)) يقصد به إخراج كل ما يصدر عن غـيره

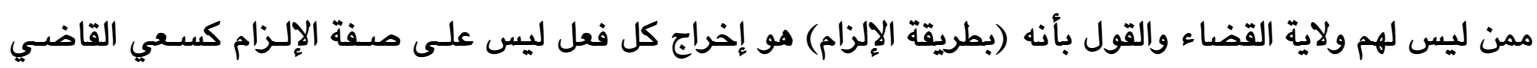

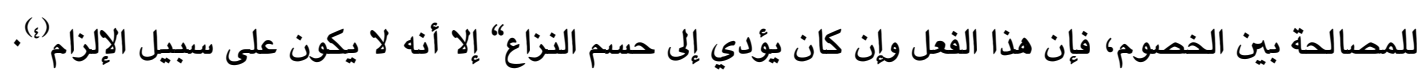
الحكم القضائي في الاصطلاح القانوني. "هي القرارات التي تصدرها المحكمة في منازعة رفعت إليها طبقاً لقانون المرافعات" ومن هذا التعريـف يجب أن يتوفر في الأحكام شرطين هما: أولاً: أن تصدر الأحكام من قبل السلطة القضائية، التي تتشكل على وفق القانق القان.

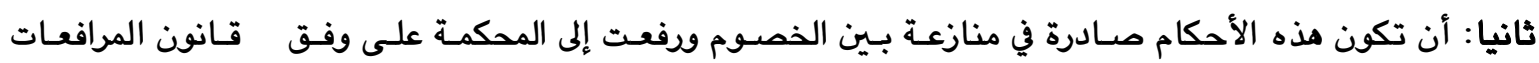
المدنية (ه).

(1) ينظر : د ـ محمد الزحيلي، التنظيم القضـائي في الفقه الإسـلامي، دراسـة مقارنـة، دار الفكر ، دمشق، سوريا، .

(Y) ينظر : د . ع عدنان بن محمد بن عنيق الدقيلان، الدعوى القضائية في الفقه الإسلامي، طا د دار أبن الجوزي للنشر

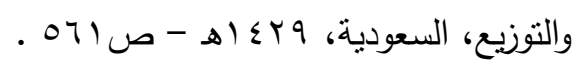

(ץ) ينظر : علي حيدر، درر الحكام شرح مجلة الاحكام، طا، تعريب المحامي فهي الحسيني، المجلد الرابع، دار

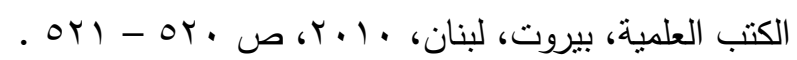

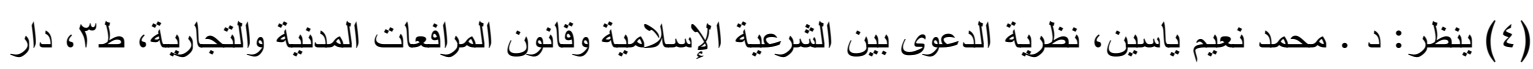

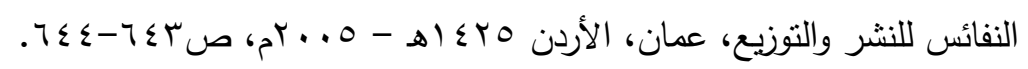

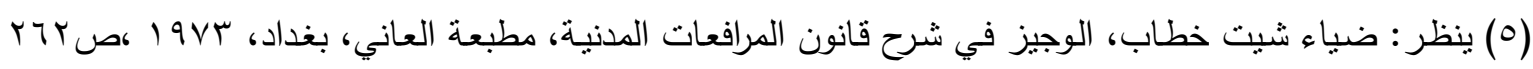

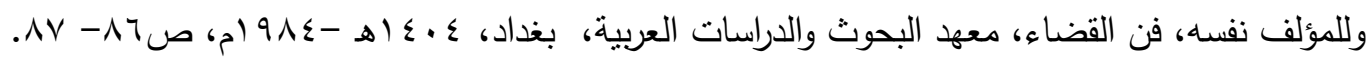


لذا ذهب رأي من الفقه القانوني إلى الحكم بأنـه لا يحـوز الحجيـة ولا يكون قطعيـا، إلا إذا صـدر إثر نـزاع بـين

الخصوم ما لم تكن المسألة التي صدر فيها الحكم من النظام العام وتعدّ مطروحة من تلقاء نفسها على المحكمة (1).

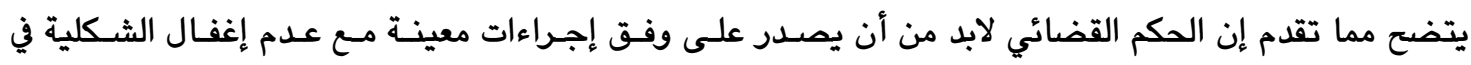
إصدار الحكم القضائي ويخلاف مذا القول فان الحكم القضائي لا يستجمع شرائطه القانونية، وفي هـذا الاتجـاه ذهبـ إنـ

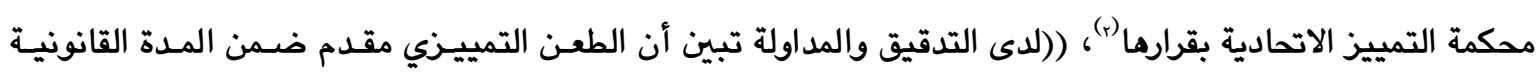

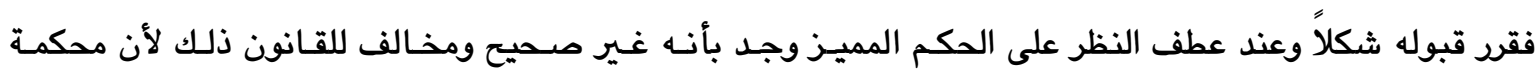

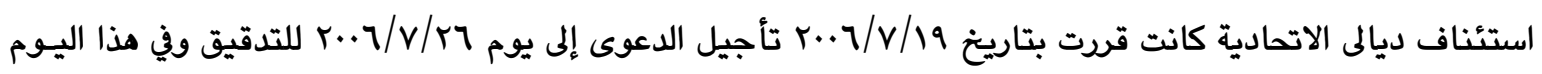

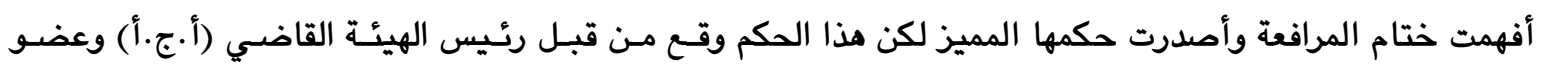

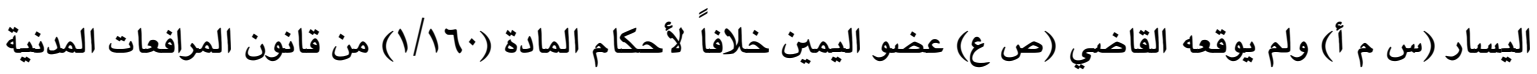

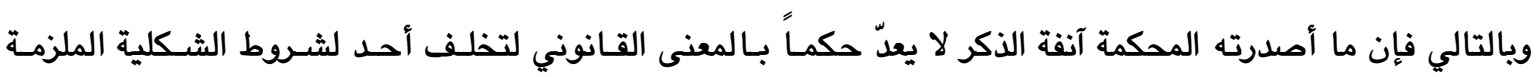

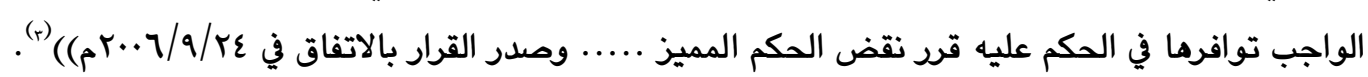

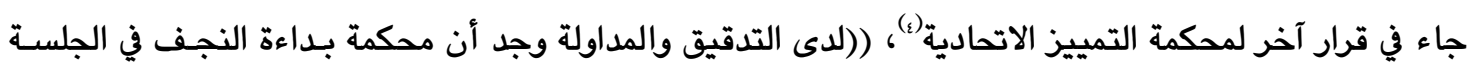

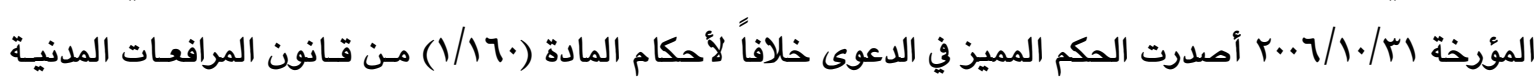

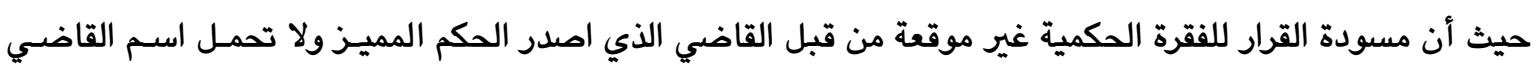

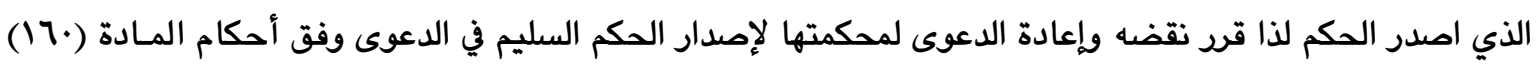

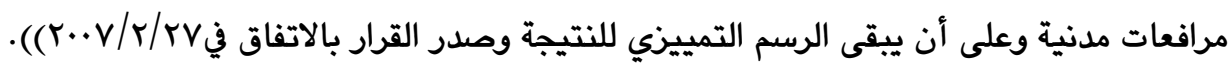

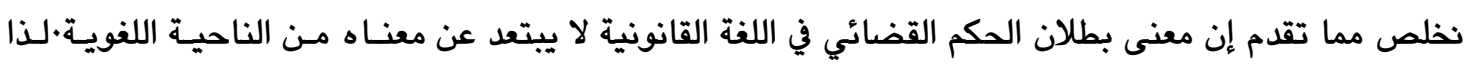
عرف بطلان الحكم القضائي بأنه هو: ((جزاء يرتبه المشرع أو تقضي به المحكمة بغير نص إذا افتقد العمل القانوني

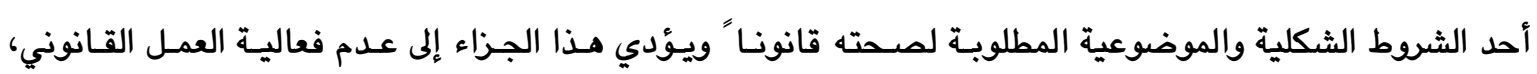
وافتقاده لقيمته المفترضة له في حال صحته ()) (ه). تعددت مذاهب البطلان في الفقه القانوني التي يمكن إيجازها في أربعة مذاهب (1)، المذهب الأول : يرتب البط البطلان

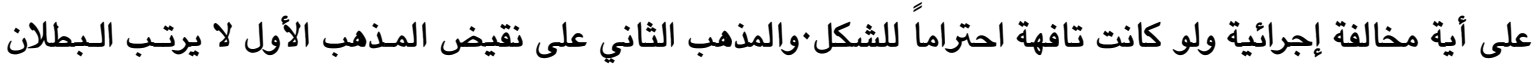

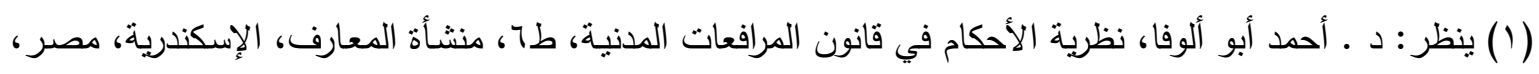
.r) (1919

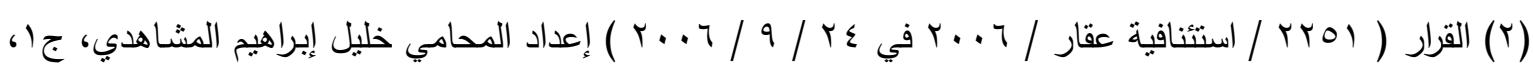

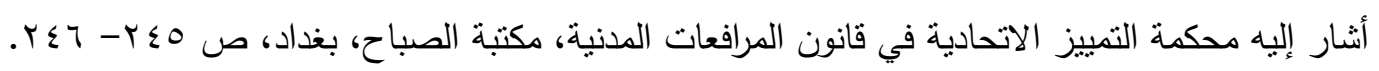

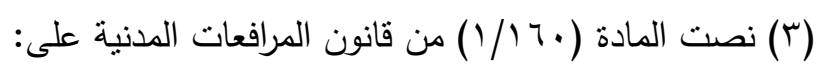

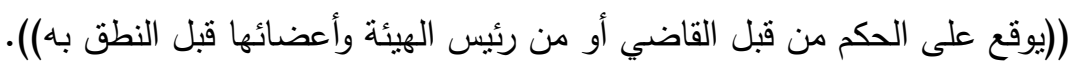

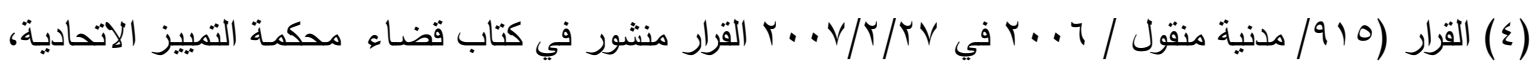

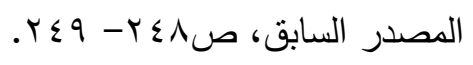

(0) ينظر : د .عبد الحكم فودة، البطلان في قـانون المرافعات المدنيـة والتجاريـة، طب، دار المطبوعـات الجامعيـة،

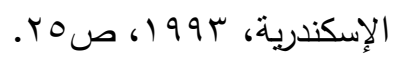

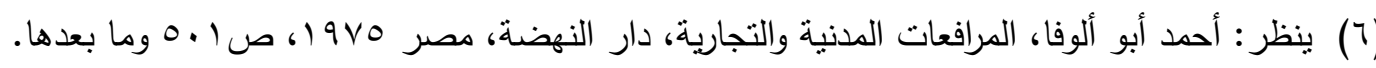


على المخالفة، بل يعد البطلان وسيلة تهديدية لحمل الخصم على احترام الشـكل، ويـترك للمحكمـة تقدير مـا إذا كـان الأمر يتطلب الحكم بالبطلان من عدمه ·أما المذهب الثالث فهو وسط بين المذهبين السـابقين فينـيط بالشـارع تحديد مواطن البطلان وعندئَذ لا يترك لمحكمة الموضوع التقدير فعليها أن توقع الجزاء، إذا نـص الشـارع ذلك، وعليها أن

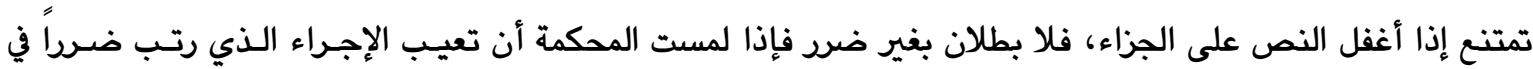
حق الخصم قضت بالبطلان، وإلا أمسكت عنه (1).

\section{|

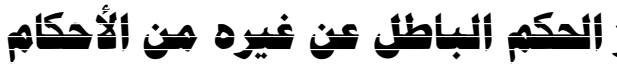

إن افتقاد الحكم القضائي لأحد شروطه الشكلية أو الموضوعية المطلوية لصحته قانونـاً بجعله عيبـاً يقدح في صحته درجة هذا العيب وتفاوته من حيث جسامته إذ قد يفضي إلى بطلان الحكم أو انعدامـه عليـه لابـد مـن التمييـز

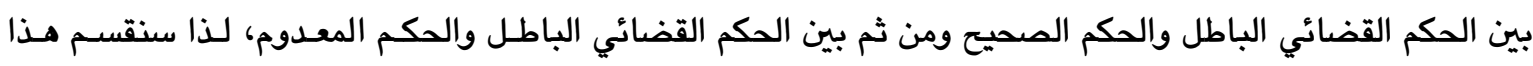
المطلب إلى فرعين نحاول أن نميز في الفرع الأول بين الحكم الباطل والحكم الصحيح ونحاول في الفـرع الثاني أن نمّيـز

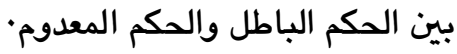

\section{|

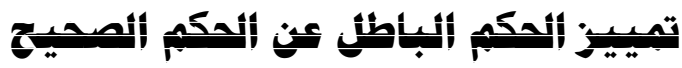

لقد سبق القول أن الحكم في الاصطلاح الشرعي ((هو قول ملزم يصدر عن ولاية عامة أو الأخبار عن حكم شرعي

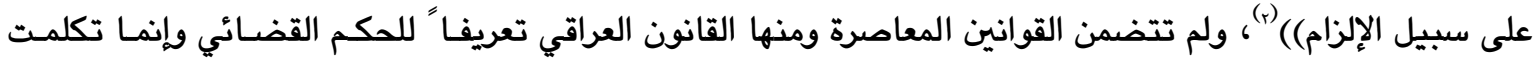
عن الحكم القضائي وكيفية إصداره والبيانات اللازمة فيه، وقد تكلمت المـادة (rT (17) مـن قـانون المرافعـات المدنيـة العراقي عن كيفية إصدار الحكم والبيانات اللازم ذكرها من الحكم القضائي إذ نصت على: ((بعد النطق بالحكم يـنظم

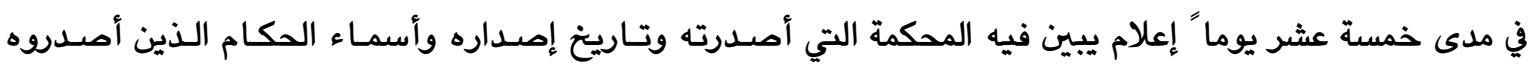
وأسماء الخصوم وأسماء وكلائهم وإثبات الحضور والغياب وخلاصة الدعوى وموجز ادعاءات الخصوم ودفوعهم ومـا

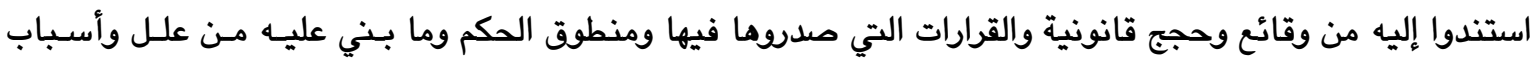
والمواد القانونية التي استند إليها ويوقع من قبل الحاكم أو رئيس الهيأة ويختم بختم المحكمة))، فالحكم من الأعمال الإجرائية عملي شكلي وتظهر الشكلية في أمرين هما : كتابته والنطق به (r).

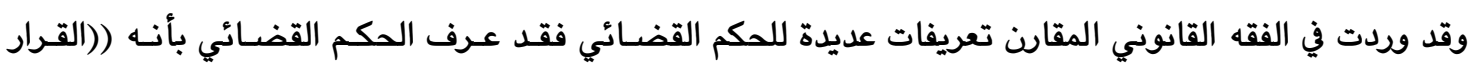

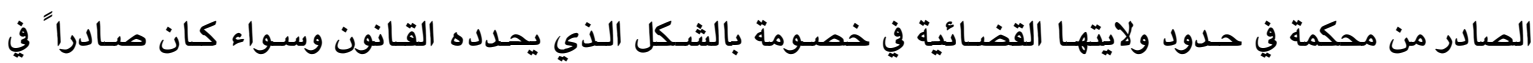

(1) ينظـر : د. أحمــ أبـو ألوفـا، المسـتحدث في قـانون المرافعـات الجديــ وقـانون الإثبـات، طا، منشـأة المعـارف،

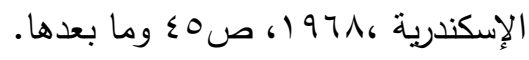

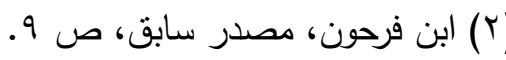

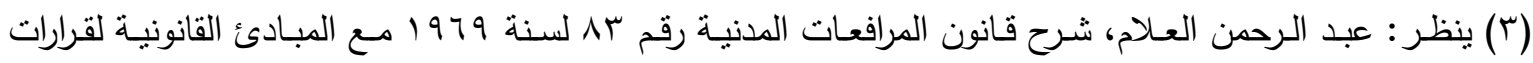

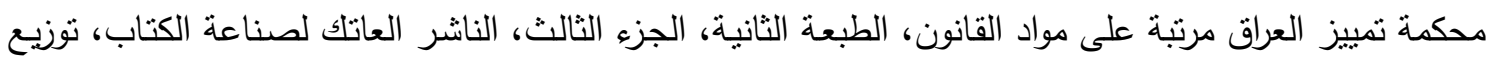


موضوع الخصومة أم في مسألة إجرائية))(1)، وعرف الحكم بأنه ((الحكم بمعناه الخاص، مو القرار الصادر من محكمة

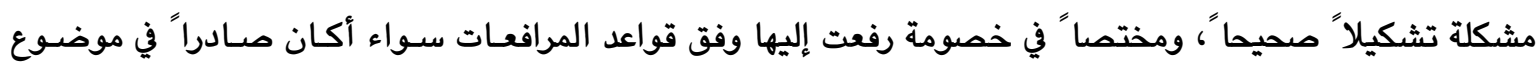

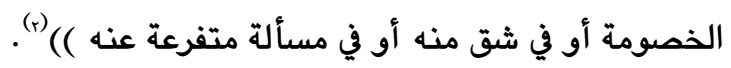
إن الغاية من ذكر هذه التعريفات الوصول إلى حقيقة الحكم القضائي الصحيح الذي يمكن بيـان فكرتـه بصـورة مبسطة بأن الحكم القضائي الصحيح هو الحكم الصادر من محكمة في مشـكلة تشـكيلاً صحيحاً في حدود ولايتها في لئي خصومة مع مراعاة الشكل الذي يحدده القانون للأحكام. أما الحكم الباطل فهو الحكم الذي يكون مشوياً بعيـب سـواء مـن ناحيـة إصـداره، في إجراءاتـه الشـكلية، أو في

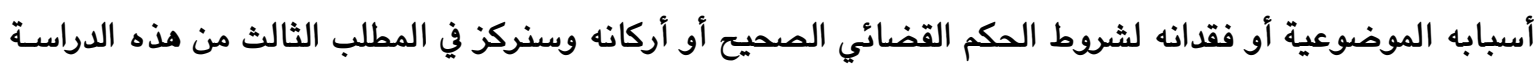
على الأسباب (الشكلية والموضوعية) لبطلان الحكم القضائي·

ومن الجدير بالإثارة التمييز بين أركان الحكم ومقومات وجوده وبين شروط انعقاده وذلك بصورة موجزة(r). وللحكم أركان موضوعية أو داخلية تتعلق بمضمون الحكم هي (الإرادة والمحل والسبب) وأركان شكلية خارجيـية وهي (القاضي) المطالبة القضائية، شكل (الحكم) وهي أساس وجوده من دونها يتجرد الحكم من العناصـر الجوهريـة اللازمة لتكوينه، ويفقده صفة الحكم مما يعني انعدامه فلا يرتب أي آثار قانونية. أما شروط الانعقاد أي صحة انعقاد صدود الحكم، فهي الشروط الـتي يسـتلزم القـانون توفرهـا في مـذه الأركان

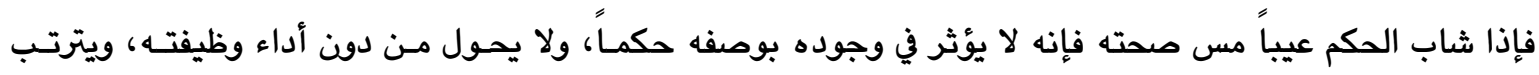

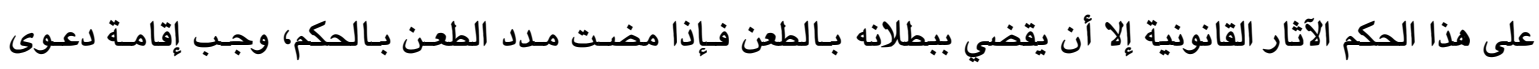
أصلية بالبطلان. وخلاصة القول أن الحكم القضائي الباطل هو الحكم المشوب بعيب عدم تطابق الحكم مع نموذجه القانوني، وأن يرتب القانون على هذا العيب عدم إنتاج الحكم لآثاره القانونية التي تترتب عليه إذا كان صحيحاً أي خالياً من عيبه

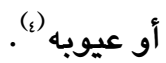
وبهذه المعايير تتبلور فكرة التمييز بين الحكم القضائي الباطل والحكم القضائي الصحيح.

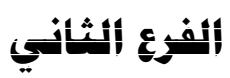

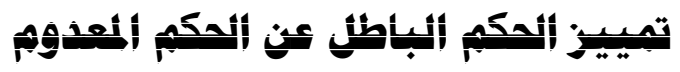

يُعدّ الانعدام - نوعاً من أنواع البطلان في القانون الخاص ــ من الأفكار الـتي تتميـز بحداثتها، ولعل مـن أبـرز

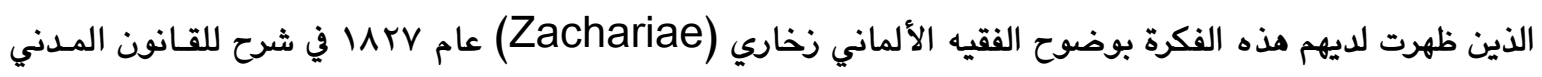

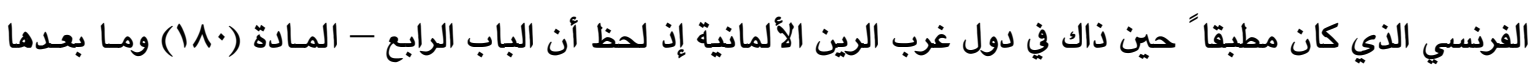

(1) ينظر : د. .محمد سعيد عبد الرحمن، الحكم القضائي أركانه وقواعد إصداره، دراسة تأصيلية تحليلية تطبيقية مقارنة،

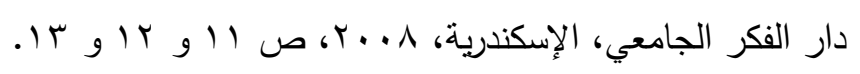

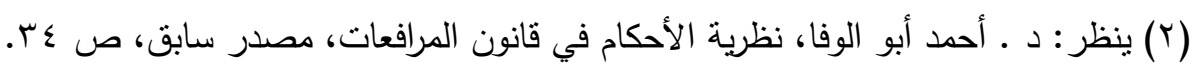

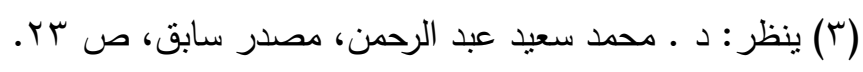

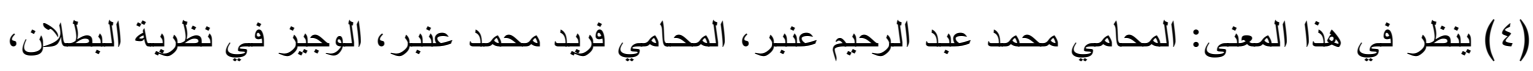

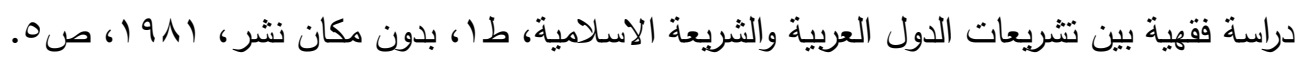


- قد عدد الأسباب المختلفة لبطلان الزواج، ووضح أن القضاء قد أقر صراحة أن هذا التحديد قـد جـاء على سبيل الحصر وليس المثال، ومن ثم فلا بطلان في مسائل الزواج إلا بنص. إلا أن الواقع العملي أفرز حالات لم ينص عليها القانون على البطلان وفي الوقـت نفسـهـ لا يستسـاغ القـول بـترك

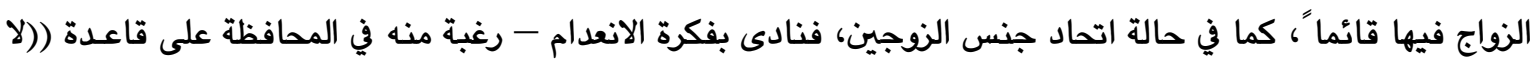
بطلان في مسـائل الـزواج إلا بـص)) مميـزا" بـين شـروط وجـود التصـرف (RechticheWesen)) وشـروط

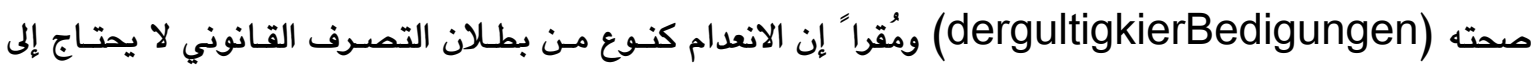
نص لتقريره") وذهب الفقيه جابيو إلى أن ديمولومب هو أول من قرد فكرة الانعدام إذا إنه أول من أعطى لاصـطلاح

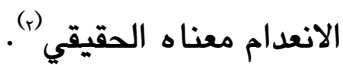
إن مظهر الانعدام عدم الوجود ومظهر أو جزاء عدم الصحة هـو البطلان، إذ يختلف الانعـدام عـن البطلان “لأن مصدرهما التباين بين عدم الوجود وعدم الصحة، وإن الحكم المعدوم لا يرتب أي أثر قانوني، ويترتب الانعـام بقـوة

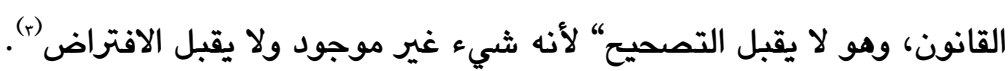
وفي هذا الاتجاه ذهبت محكمة التمييز في العراق إلى مبدأ نفاده ((القرار المعدوم لا تلحقه حصانة ولا يترتب عليـ مهاهيه

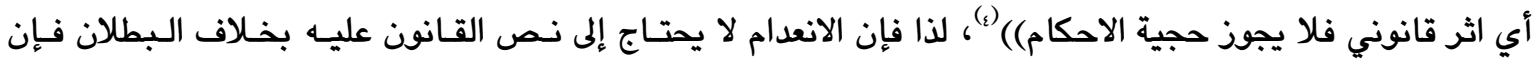

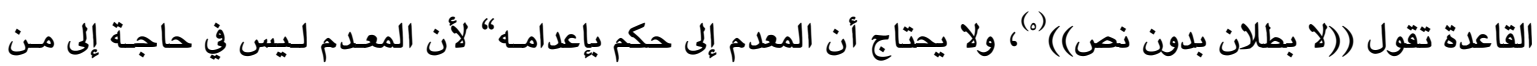

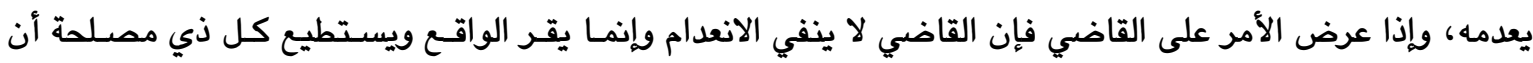
يتمسك بالانعدام، وأن عرض للقاضي حكم منعدم فعليه أن يقر الانعدام من تلقاء نفسه. ولا شك أن فكرة الحكم المعدوم لا يقتصر نطاق تطبيقها على الاحكام المدنية ولها حضور في الاحكام الجزائيسة،

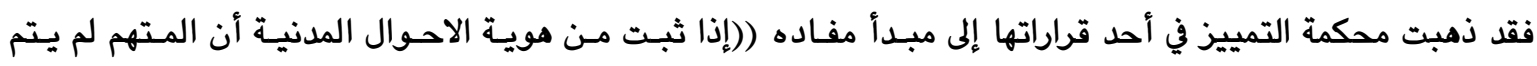
الثامنة عشر من العمر وكانت الهوية تستند إلى بيان ولادة فيكون تولده ثابت بموجب هوية الأحوال المدنيـة ولا يغـير هـير من ذلك شيء تقرير اللجنة الطبية بتقدير عمـره وتكون محكمـة الأحـداث هـي المختصـة بمحاكمتـهـ واعتبـار الحكم

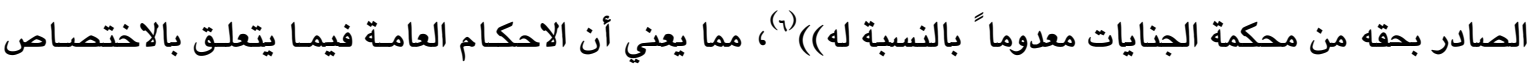

( ) للمزيد ينظر : د . رمزي طه الثاعر ، تدرج البطلان في القرارات الادارية دراسة مقارنة، طس، دار الكتب المصرية،

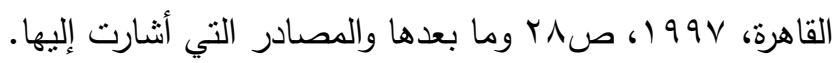

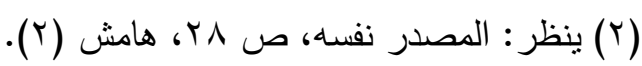
(ץ) ينظر : القاضي شهاب أحمد ياسين، انعدام الاحكام، طا، شركة العاتك لصناعة الكتاب، القاهرة، المكتبة القانونية،

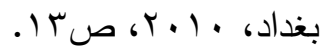

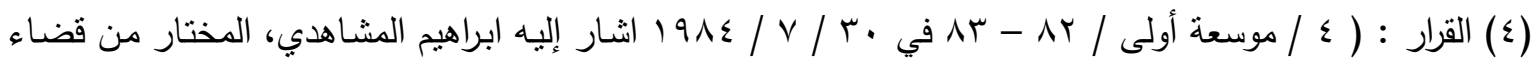
محكمة التمييز، قسم المرافعات المدنية، الجزء الثالث، مطبعة الزمان، بغداد، 999 1، ص IVV.

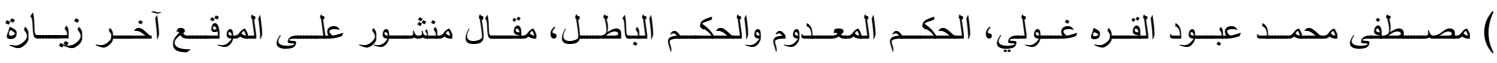
http://www.uobabylon.edu.iq/uobColeges/service_showrest.aspx?f $(r \cdot 1 r / 1 / / 0)$

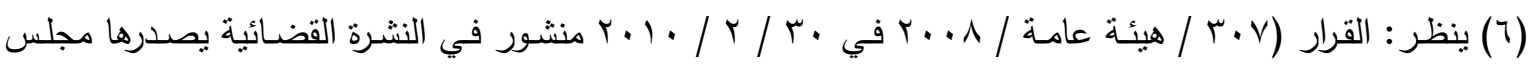

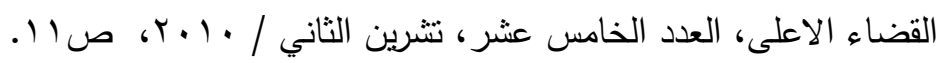


النوعي للمحاكم المدنية ينسحب على الاختصاص النوعي في محاكم الجزاء"). فالحكم المعدوم لا أثـر لـه ابتـاء، ولا

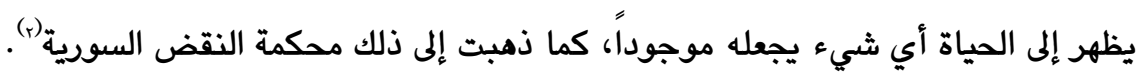
يُعد الحكم الذي يصدر خلافاً للاختصاص النوعي للمحاكم حكماً معدوما" وفي هذا الاتجاه ذهبت محكمة التمييز

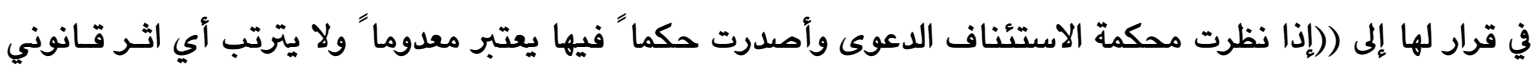

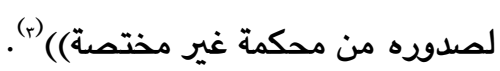
أخذ الفقه القانوني بالتوسع في فكرة الحكم المعدوم إذ يعد مخالفة الحكم القضائي لمبادئ الشريعة الإسلامية من

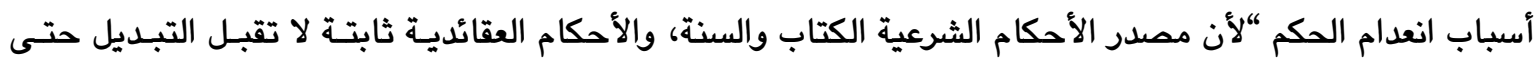

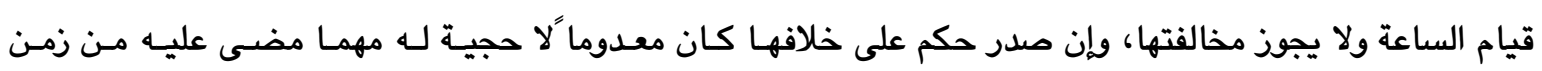
ويكفي جدده وإنكاره، فلا يعدّ هذا الحكم باطلاً" لأن الحكم الباطل إن لم يطعن فيه حاز قوة الأمـر المقضـي وصـار

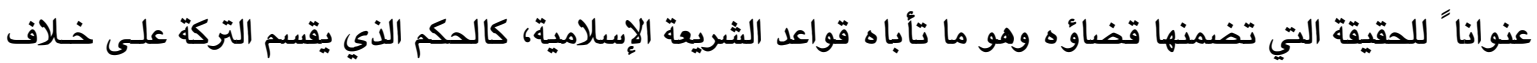
الأنصبة الشرعية وما تضمنته سورة النساء، وإذا كان هذا القول يصدق على المسائل التي ورد بشأنها نـص محكم، فإن الأمر محل نظر واجتهاد في المسائل التي لم يرد فيها نص محكم، فإن انتظمها نص في القانون الوضعي كـان هـو

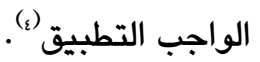
إن الأثر المترتب على مخالفة الحكم (( للنظام العام)) على حد تعبير رجال الفقه القانوني هو انعدام الحكم ومـن هذه الحالات حالة انعدام الخصومة بإقامة الدعوى على شخص ميت، وفي هذا الاتجاه ذهبت محكمة استئناف كركوك

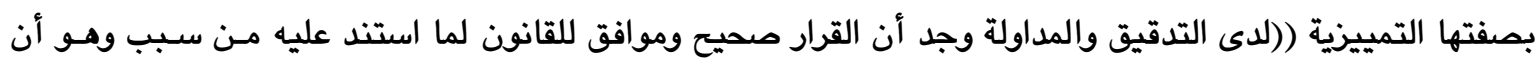

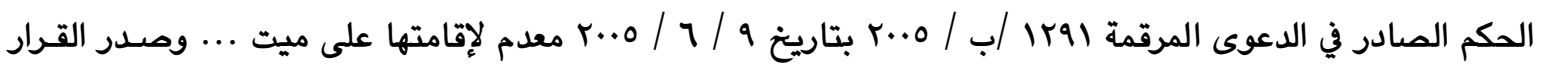

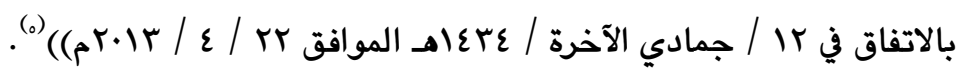

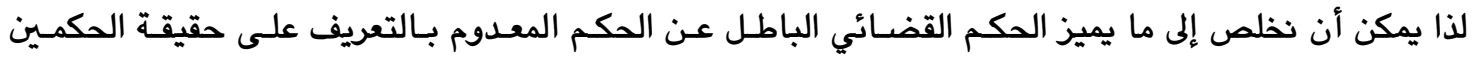
بوساطة التعريفات التي وضعت لهما، فقد عرف الحكم القضائي الباطل بأنه هو ((الحكم القضائي المخـالف للنمـوذج القانوني الذي رسمه المشرع، والذي شابه عيب في شروط صحة انعقاده وقواعد إصداره أو بسبب إجراء باطل سـابق

(1) ينظر : القاضي عواد حسين ياسين العبيدي، شرح قانون رعاية الأحداث رقم Y ل لسنة به9 ا، طا ، مكتبة الجيل

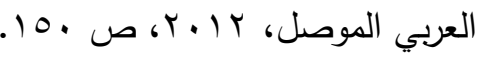

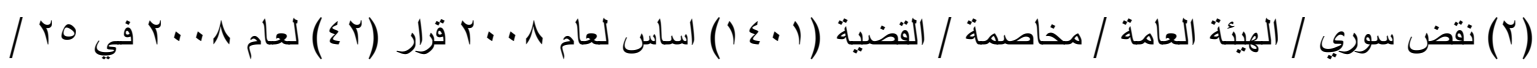

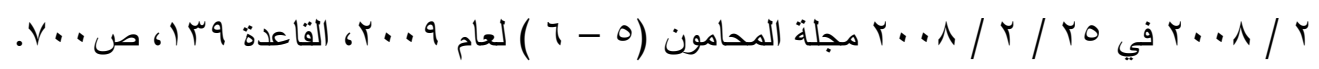

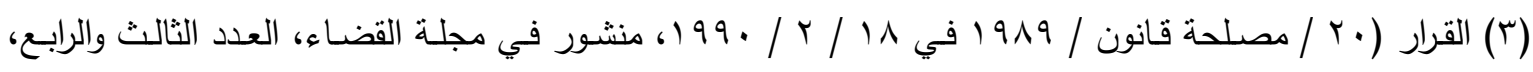

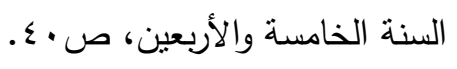

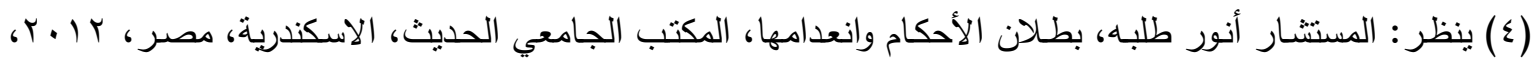
ص ص 099.

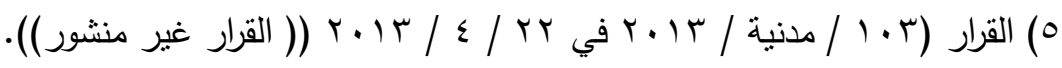


بني عليه، يؤثر فيه ولكن لا يعدمه، ويحوز حجية الأحكام حتى وإن كان بطلانه متعلقاً بالنظام العام “ وذلك عندما لا يطعن فيه)() (1)

عرف الحكم المعدوم بحسب الاجتهاد القضائي بأنه ((هو الحكم الذي فقد ركناً جومرياً من أركانه الرئيسة))(r)"،

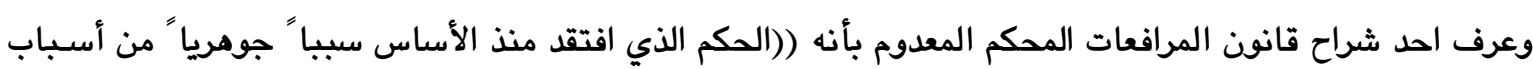
تكوينه وهو بذلك تكوّن ولم يوجد (r). عرفت محكمة التمييز في العراق الحكم المعدوم في احد قراراتها بأنـه ((الحكم الذي لا يرتـب أي أثر قـانوني ولا

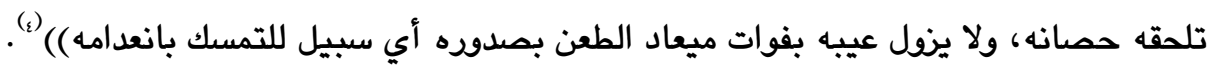

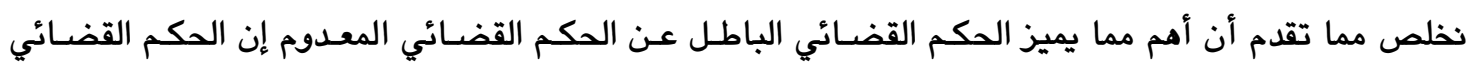

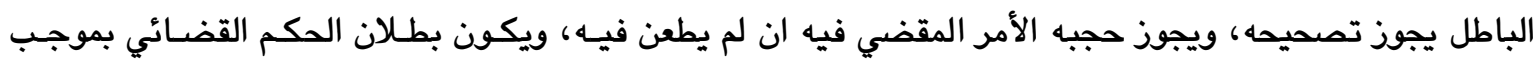
نص يحكمه تطبيقاً لقاعدة ((لا بطلان إلا بنص)) أما الحكم القضائي المعدوم فهو عدم والعدم لا يولد إلا العدم لـذا لذا لها

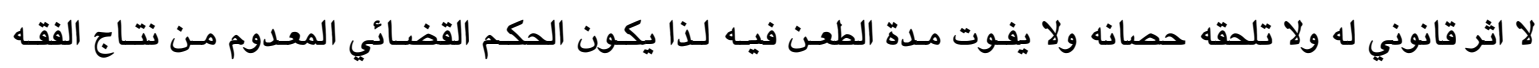
القانوني، واجتهاد القضاء.

\section{ثtifi itifi

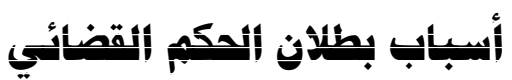

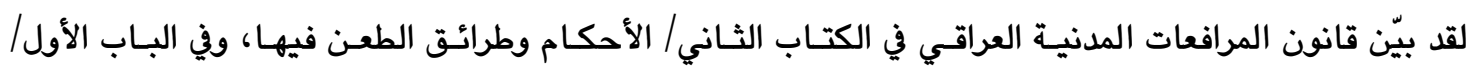

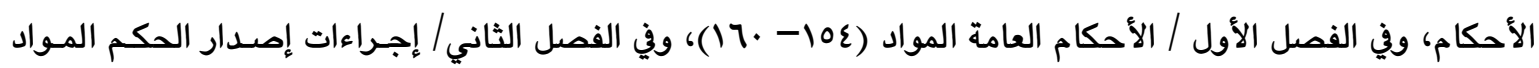

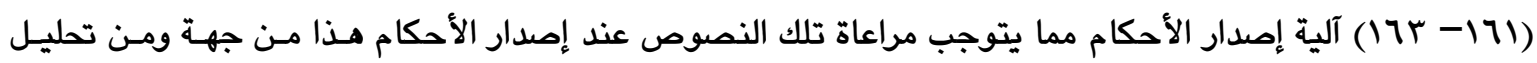
تلك النصوص القانونية يمكن التوصل إلى أسباب بطـلان الحكم القضـائي والـتي يمكن إرجاعها إلى أسـباب شـكلية وأسباب موضوعية فضلاً" عن معرفة الآثار المترتبة على بطلان الحكم القضائي من جهة أخرى.

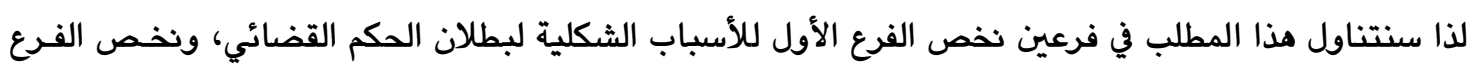
الثاني للأسباب الموضوعية لبطلان الحكم القضائي.

(1) ينظر : صدام خزعل يحيى، النظام القانوني للحكم الباطل، دراسـة مقارنة رسالة ماجستنر مقدمة لكلية الحقوق،

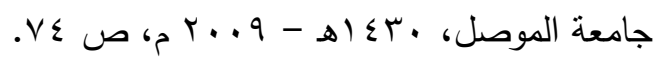

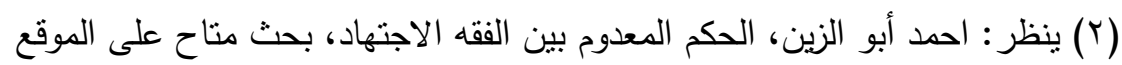
http: // www. Justice -lawhome . com / vb/ showthresd . php ?t

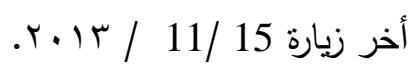

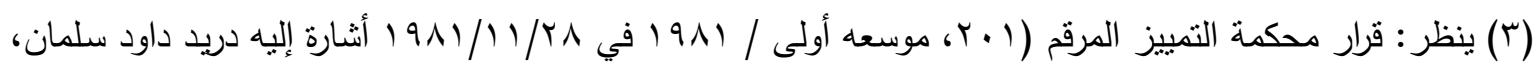

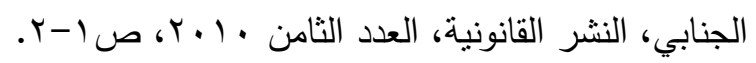

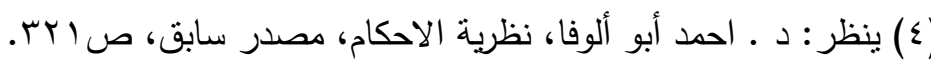




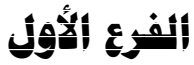

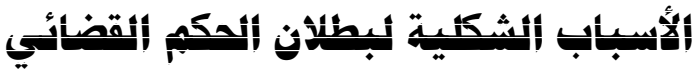

هناك أسباب شكلية عديدة لبطلان الحكم القضائي ومن هذه الأسباب ما يأتي: أولاً: سماع الذصم في غيبة الآخر. إن من الأصول الثابتة في القضاء هو عدم جواز بنـاء الحكم على أقـوال أحـد الخصـوم مـن دون سمـاع أقـوال

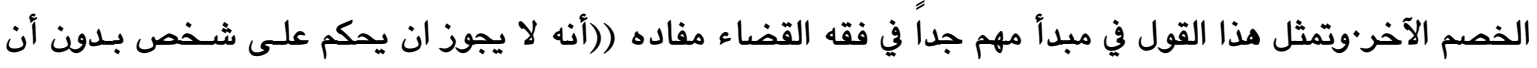

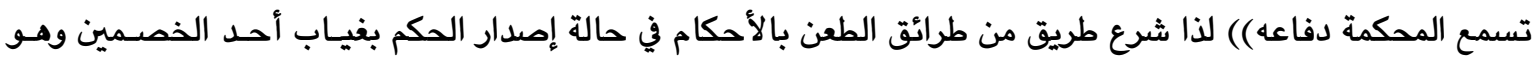

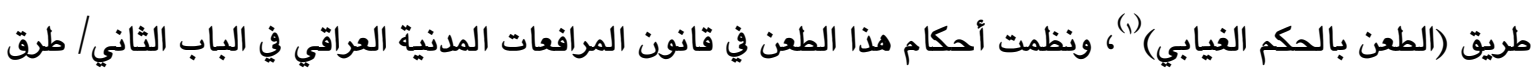

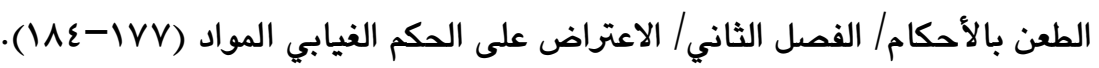

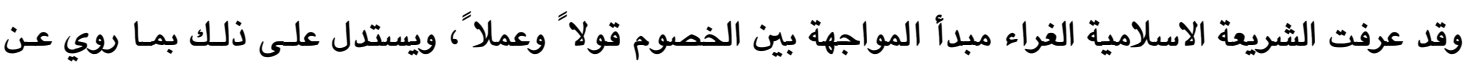

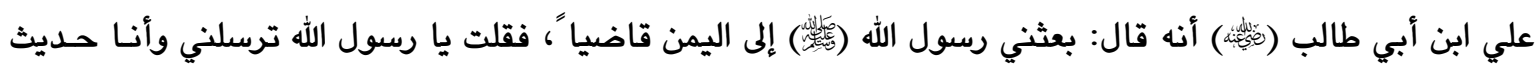
السن ولا علم لي بالقضاء، فقال: إن الله سيهدي قلبك ويثبت لسانك، فـإذا جلس بـين يـديك الخصـمان فـلا تقضـين

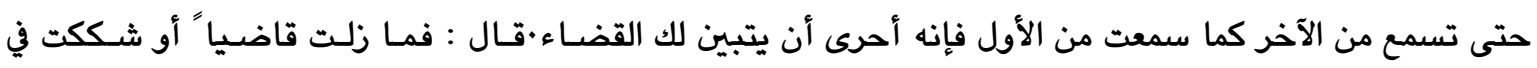
قضاء بعد (r).

وتناول الفقهاء المسلمون هذا المبدأ تحت عنوان ((القضاء على الغائب)) (r)، إذ روي عـن عمـر (رض) أنه أتـاه رجل قد فقئت عينه، فقال له عمر: تحضر خصمك، فقال له يا أمير المؤمنين أما بك من الغضـب إلا مـا أرى؟ فقــال

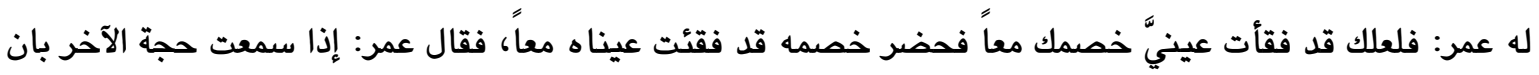

(1) ينظر : القاضي مدحت المحمود، شرح قانون المرافعات المدنية رقم rم لسنة 979 1، دراسة تطبيقية، ط ا، بغداد، ....

(r) الإمام أبو داود سليمان بن الأشـعث السجستاني الأزدي، سنن أبي داود، طا، جr، المجلد الثالث، دار المعرفة

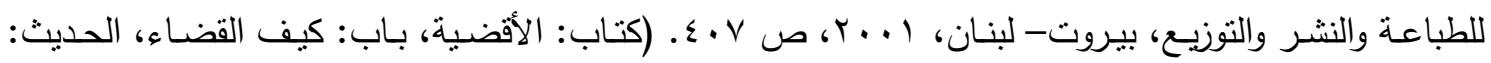

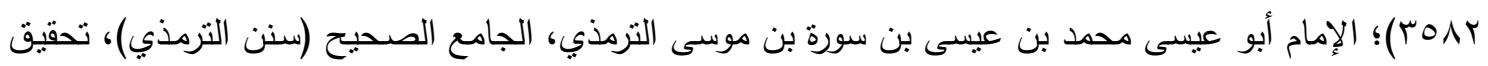

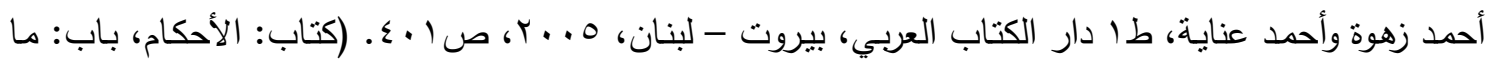
جاء في القاضي لا يقضي بين الخصمين حتى يسمع كلامهما، الحديث: (بس ا)؛؛ الإمام أبو عبد اله محمد بن يزيد

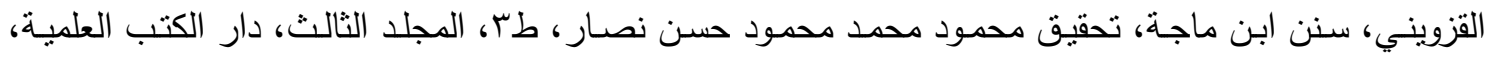

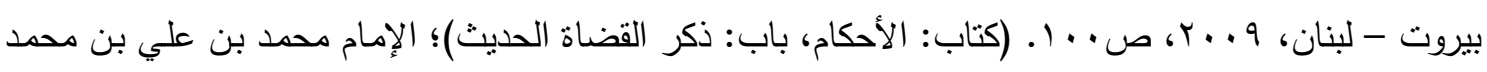

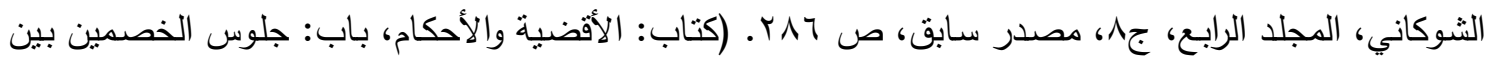

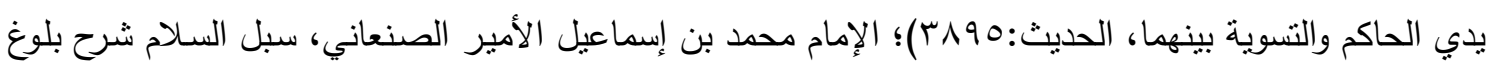

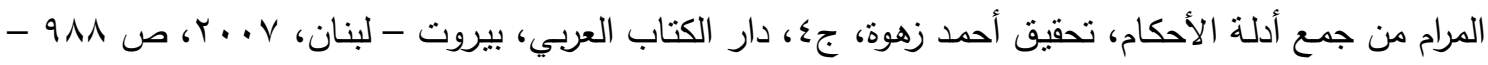

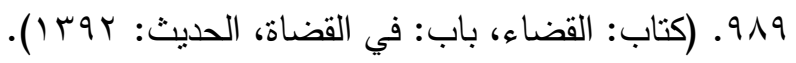
(r) ينظر : د. محي هلا السرحان، النظرية العامة للقضاء في الإسـلام، مركز البحوث والدراسات الإسـامية، ديوان

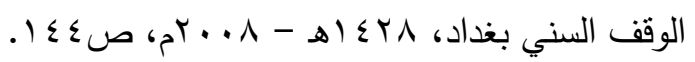


القضاء") فيستدل مما تقدم إذا لم يحضر الخصم لم يصح الحكم(r)، و ذهب الفقه الإسلامي إلى أن غيـاب الخصـم لا

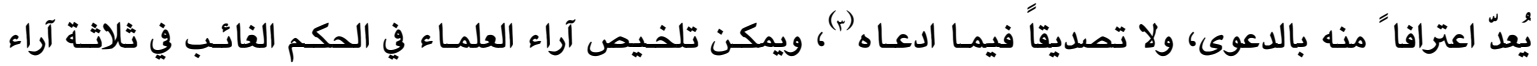
الرأي الأول: - n

يجوز القضاء على الغائب سواء أكان في حق من حقوق الله تبارك وتعالى أم في حق مشترك، وهذا قول الحنفية. الرأي الثاني: يجوز القضاء على الغائب فيما هو حق لآدمي ويمنع القضاء عليه فيما هو حق الله تعالى وهو قول الجمهور. الرأي الثالث: يجوز القضاء على الغائب سواء كان حق الله تعالى أم حق للعبد وهذا القول للظاهرية. والرأي الراجح هو قول الجمهور، وهو جواز الحكم على الغائب لقوة أدلته، ورجاحـة حجبـهـ ولاجتمـاع السـواد الأعظم من الفقهاء المسلمين على العمل به.

إن المرجح في نظر القضايا والمخاصمات جميعها إلى أحكام الشريعة الاسلامية فهي الأصل والاساس المعتمـد في

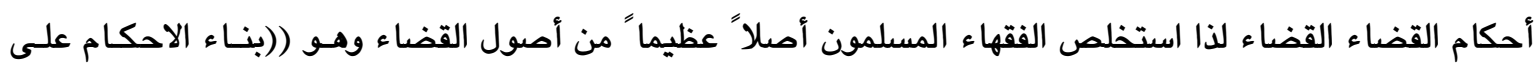
المصادر الشرعية وتأصيلها)(ه).

وإن هذا الأصل في القضاء مازلنا نلمس أثاره في أحكام قضائنا العراقي فقــ ذهبـت محكمـة التميــز في قرارهـا إلى: (وحيث أن اتخاذ القاضي القرار في موضوع الدعوى وعلى عريضتها مباشـرة قبـل استيفاء الرســ والجمـع بـين

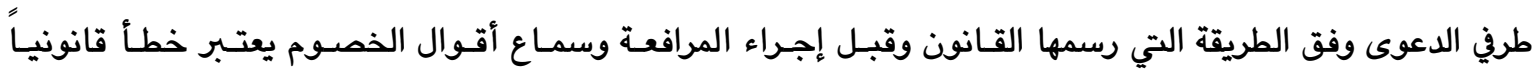

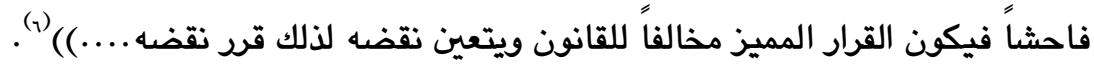
ثانياً: إصدار الحكم قبل ختام المرافعة. نصت المادة (107) مرافعات مدنية على :((اذا تهيأت الدعوى لإصدار الحكم تقـر المحكم ختـام المرافعـة، ثم

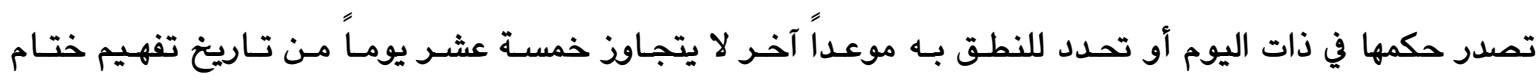

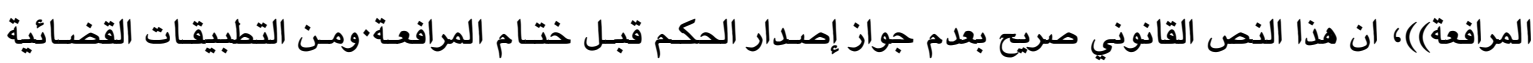

(1) ينظر : علي بن أحمد بن سعبد الأندلسي المتوفي 07 §هـ المعروف بأبي حزم، المحلى، ج. (، لطباعة المنيرية

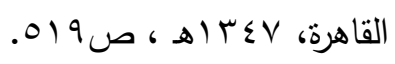

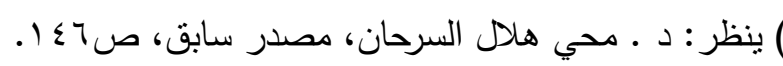
(ץ) د ـ اجياد ثامر نايف الدليمي، إبطال عريضة الدعوى المدينة للإهمال بالواجبات الإجرائية، دراسة تأصيلية تحليلية

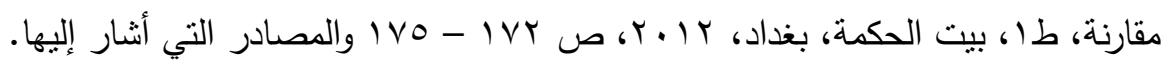

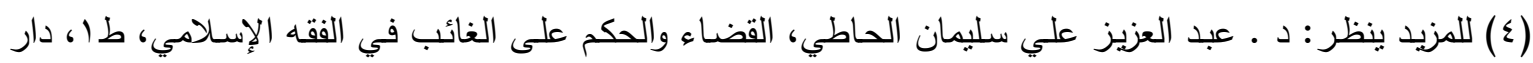

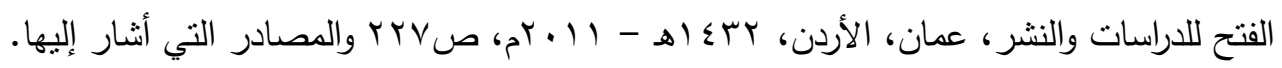

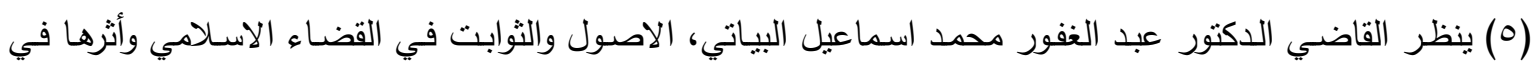

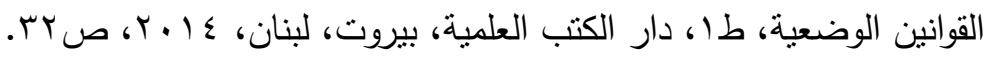

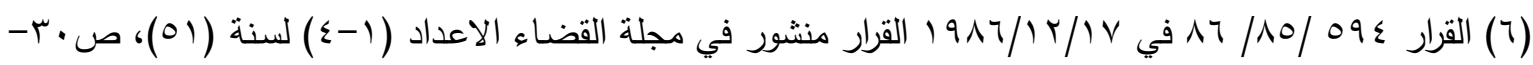


ذهبت محكمة التمييز الاتحادية في أحد قراراتها إلى())؛ ((....الحكم غـير صحيح ومخـالف للقـانون ذلك لأن محكمـة

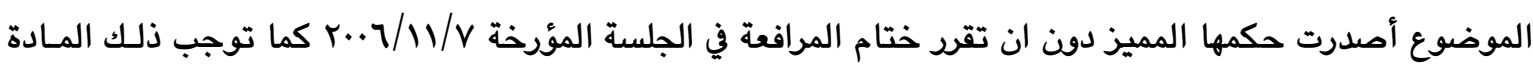

$$
\text { (107) من قانون المرافعات المدنية .....()). }
$$

ثالثاً : علانية النطق بالحكم.

نصت المادة (ال1) مرافعات مدنية على أن: ((يتلى منطوق الحكم علنـاً بعد تحريـر مسـودته وكتابـة أسبابه

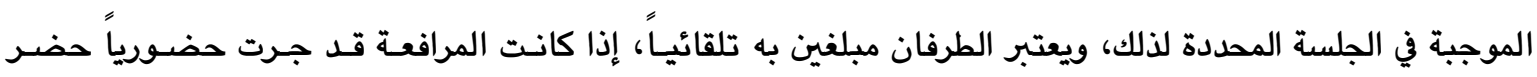

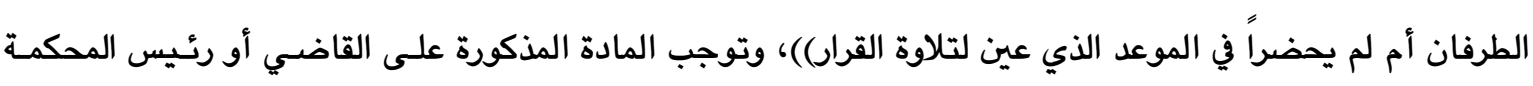
تلاوة منطوق الحكم في الجلسة علناً حضر الطرفان أو احدمما أو لم يحضرا. رابعاً : التوقيع على مسودة الحكم. ورد هذا الحكم في الشق الأخير من المادة (r7 (1) مرافعات مدنية: (...ويوقع - أي الحكم- مـن قبـل القاضـي أو رئيس الهيأة ويختم بختم المحكمة))، إن هذه المادة صريحة بوجوب توقيع مسودة الحكم من القاضي إذا كان منفرداً أو رئيس الهيئة إذا كانت المحكمة مشكلة من هيئة، مثلاً قد تكون هيئة استئنافية.ويوجب خلو الحكم مـن توقيع قاضي المحكمة أو رئيس الهيئة بطلان الحكم. فقد ذهبت محكمة التمييز الاتحادية في قرارها: (( .... ان مسودة القرار للفقرة الحكمية غير موقعـة مـن القاضي الذي اصدر الحكم المميز ولا تحمل اسم القاضي الذي اصدر الحكم لذا قرر نقضه .......)( (r).

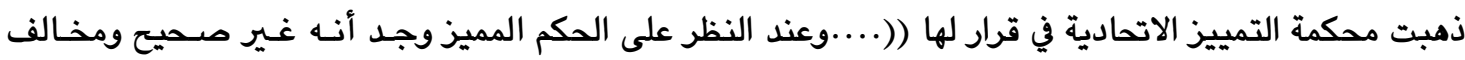

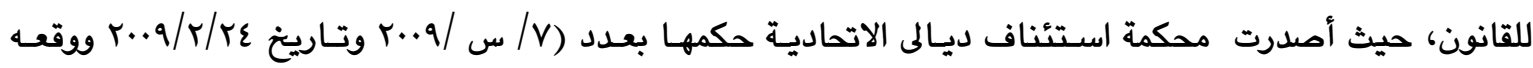
رئيس الهيأة القاضي (خ) وعضو اليمين القاضي (ص) ولم يوقعه عضو اليسار القاضي (هـ) خلافـاً لأحكام الفقرة

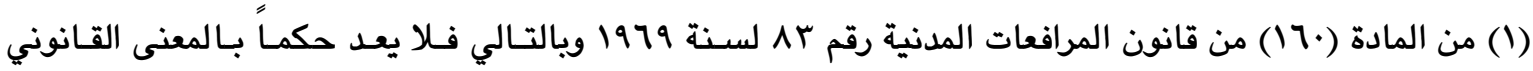

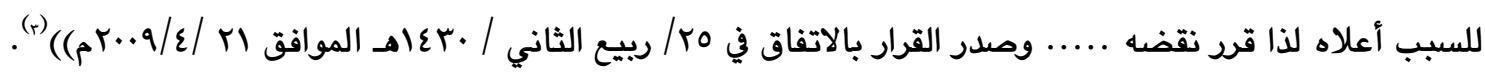

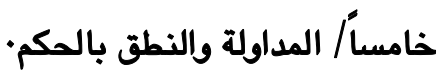
نصت المادة (101) مرافعات مدنية (تصدر الأحكام بالاتفاق أو بأكثرية الآراء، فإذا تشعبت الآراء وجب على

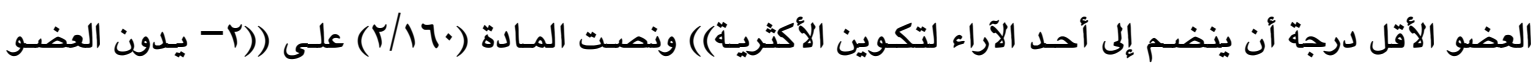
المخالف رأيه وأسباب مخالفته، ولا ينطبق بالمخالفة وتحفظ بإضبارة الدعوى ولا تعطى منها صور)).

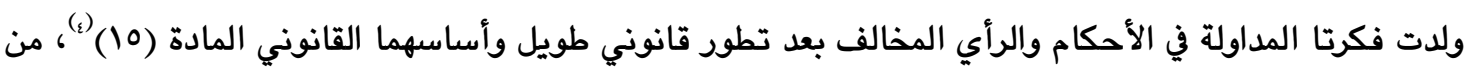

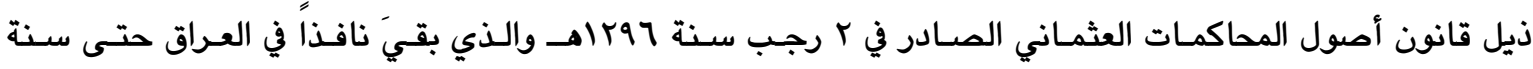

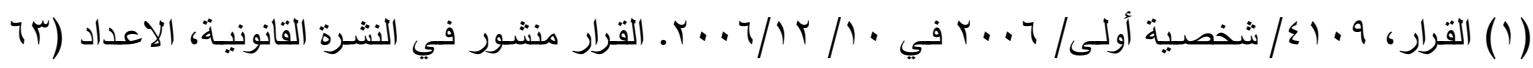

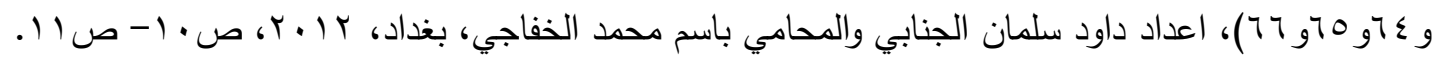

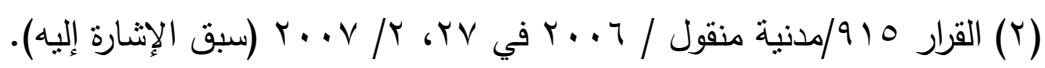

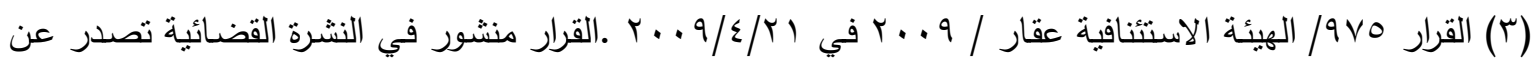

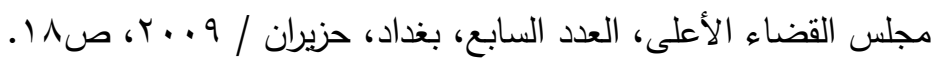

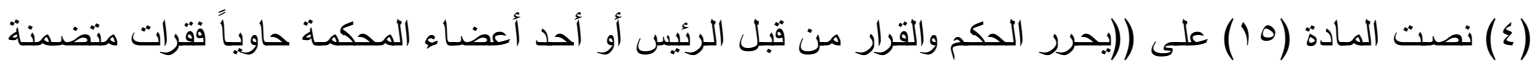
على حدة أسباب الرد والقبول في كل من المدعيات والمدافعات التي وردت في لوائح الطرفين والمواد القانونية التي= 


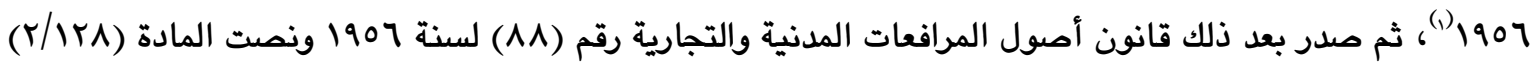

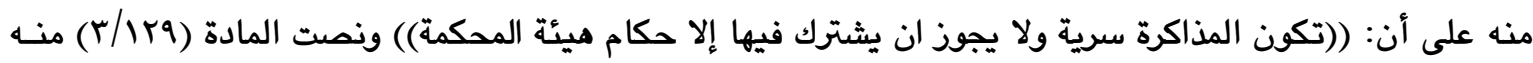
على أن (توقع هيئة المحكمة على الحكم الذي تصدره بعد أن يدون العضـو المخـالف أسـباب مخالفتـه قبـل تفهيم الحكم للطرفين)) وقد الغي القانون الأخير بالقانون الحالي النافذ رقم ب^^ لسنة 1979 المعدل.

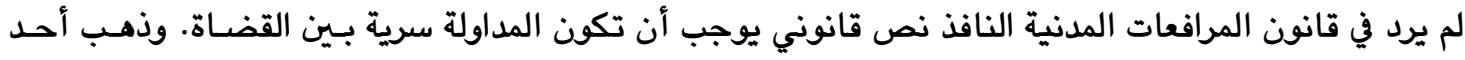

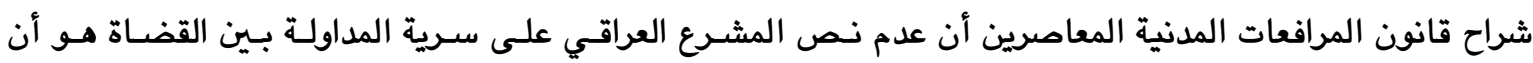
المشرع يعتقد التناقص ((بين سرية المداولة وبين تدوين الرأي المخالف، بينما لا تناقض في ذلك، لأن سرية المداولـة

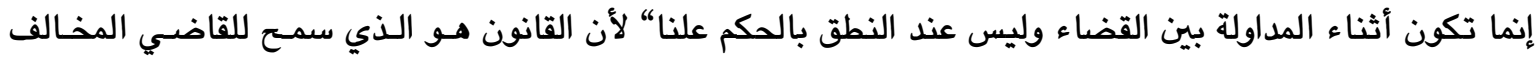

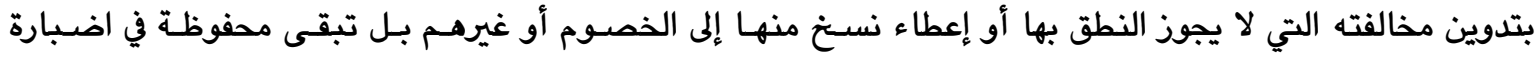

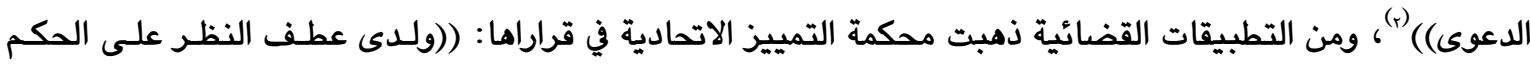

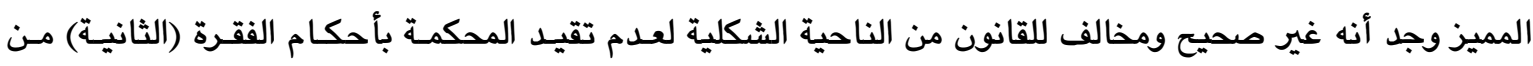
المادة (•17) من قانون المرافعات المدنية إذ لم تبين في مسودة الحكم المميز اسم العضو المخالف ولم يدون مخالفته

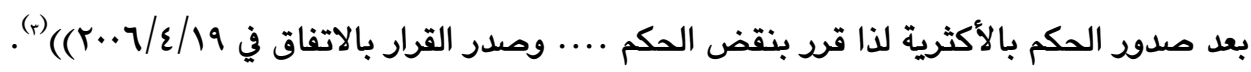
سادساً: تسبيب الحكم. نصت المادة (109/1) من قانون المرافعات المدنية على: ((ا- يجب ان تكون الأحكام مشتملة على الأسباب

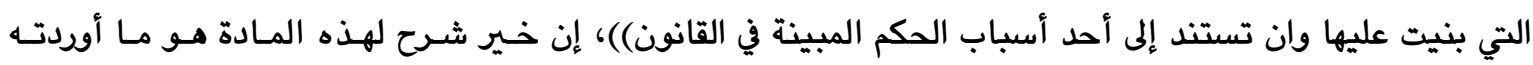

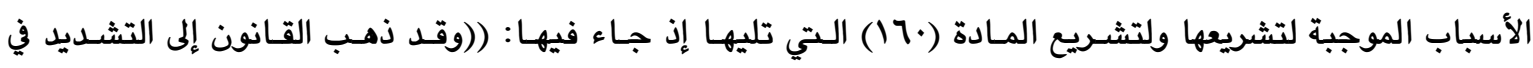

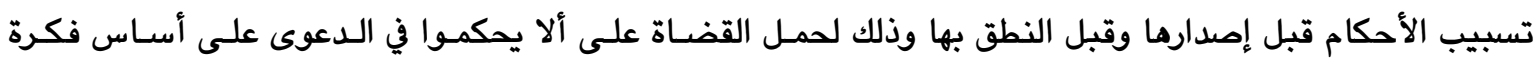

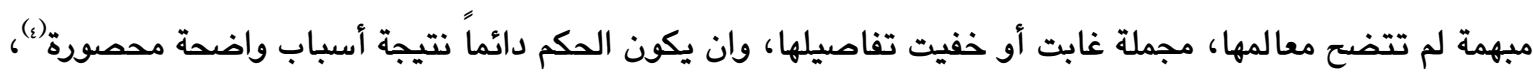
جرت على أساسها المداولة بين الحكام قبل النطق بها فإذا لم تودع الأسباب قبل تـلاوة الحكم في يـوم صـدروه فيإن

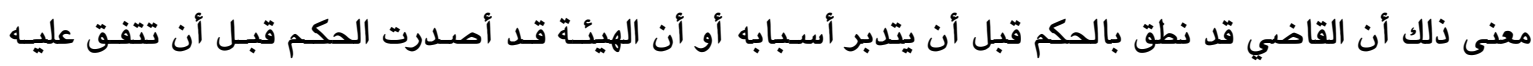
وتستقر عقيدتها على أساس معين فيه، لذا يكون الحكم قد خلا من الضمانة التي يحرص عليها الشارع)).

=استتد عليها ويوقع عليه من قبل الهيئة، وإذا كان ثمة أعضاء مخالفون لهذا القرار يكتبون في ذيل الضبط أسباب مخالفتهم بخط يدهم ويصدقون عليها بتوقيعهم ثم يقرأ رئيس المحكمة الحكم ويفهمه علانية)).

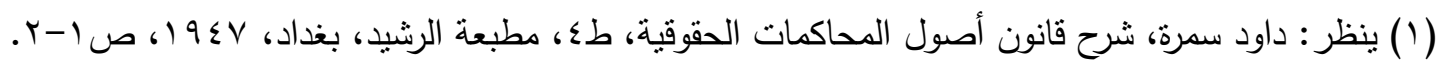

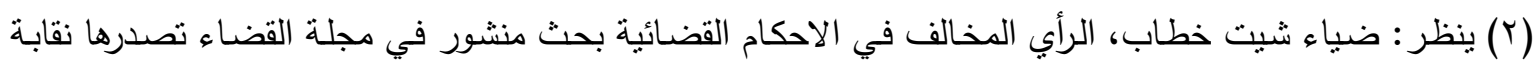

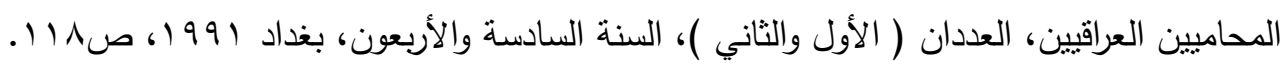

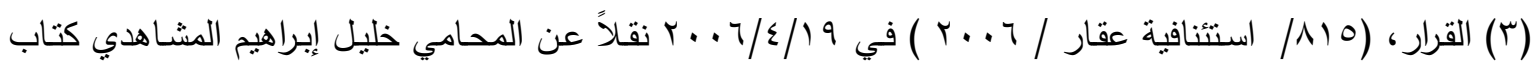

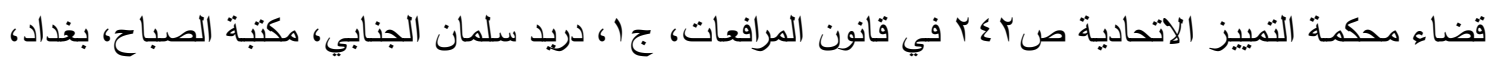


يعرف التسبيب في الفقه القانوني: ((هو بيان الأسباب الواقعية والقانونيـة الـتي قـادت القاضـي إلى الحكم الذي

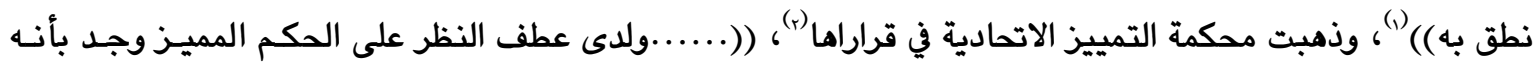

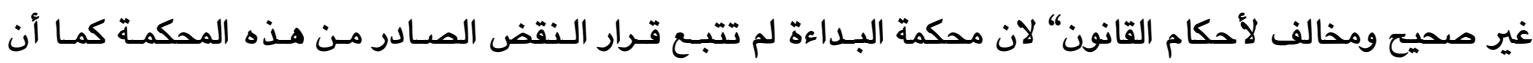

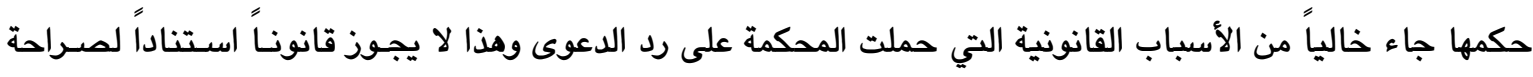
المادة (109/فقرة/16/) من قانون المرافعات المدنية والتي أوجبت على المحكمة عند إصدارها حكمها النهائي بيـان الأسباب التي استندت إليها لان التسبيب يعتبر من عناصر ومقومات الركن الشكلي في الحكم القضـائي، فـالحكم غـير إسي

$$
\text { المسبب يفتقد لروح القانون وجوهره ....()). }
$$

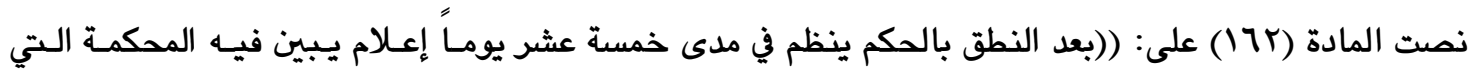

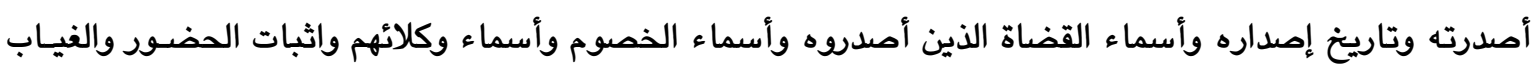

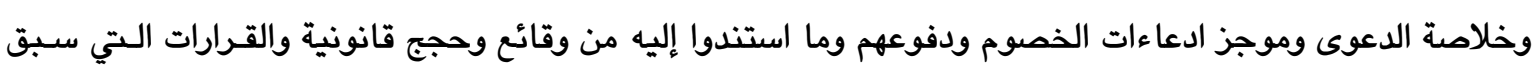

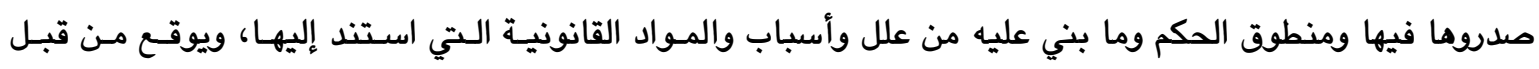
القاضي أو رئيس الهيئة ويختم بختم المحكمة)).

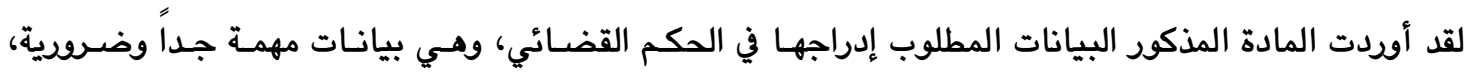

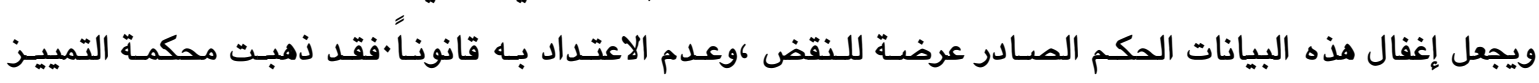

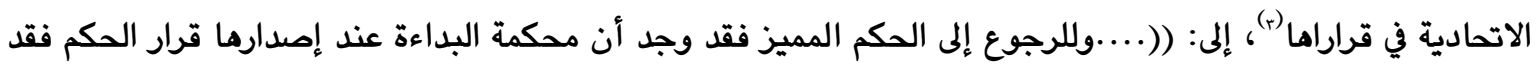

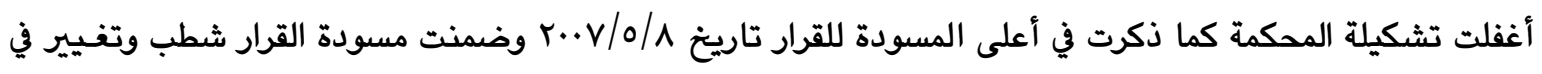
التاريخ وكون الحكم غير منظم وحيث أن اختلاف التواريخ في القرار يجعل من القرار غير معروف التـاريخ ويالتـالي لا

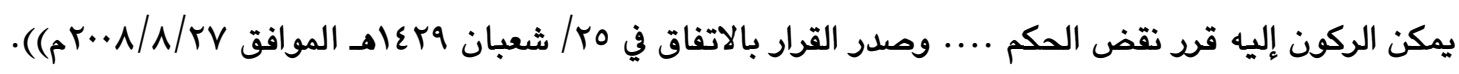
يتضح مما تقدم أن إصدار الحكم القضائي من دون مراعاة الشكلية التي أوجبها القانون بجعل الحكم القضـائي

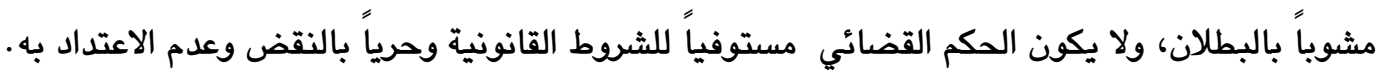

(1) ينظر : د ـ أحمد أبو ألوفـا، تسبيب الاحكام، بحث منشور في مجلـة الحقوق للبحوث القانونيـة والاقتصـادية،

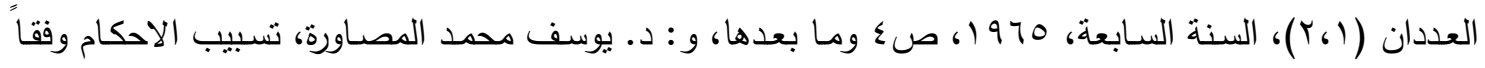

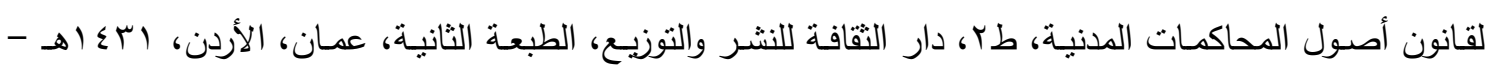
.

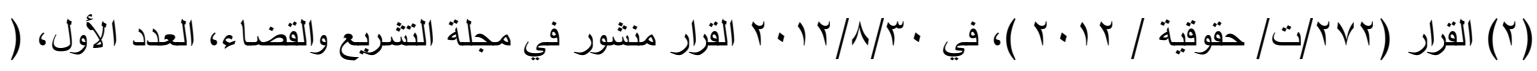

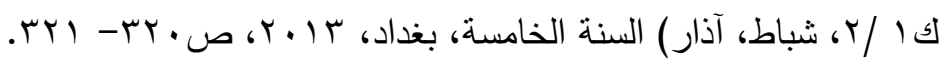

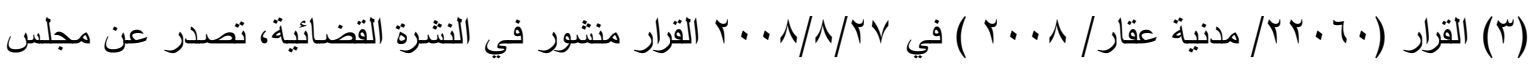

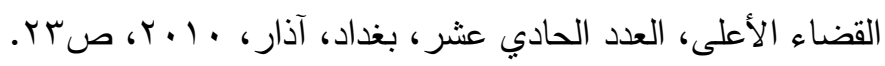




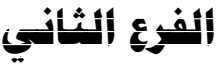

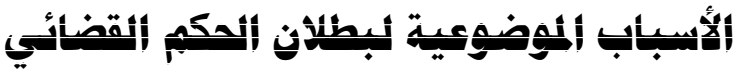

لم ينظم المشرع العراقي في قانون المرافعات المدنية بشكل واضح ومحدد الأسـباب الموضـوعية لـبطلان الحكم

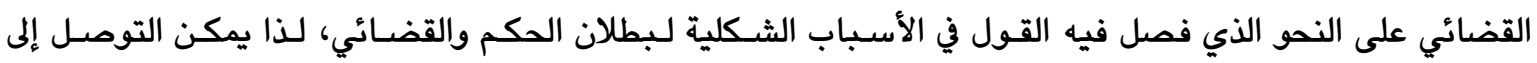
الأسباب الموضوعية لبطلان الحكم القضائي على وفق النحو الآتي : أولا": إن يكون القاضي مستوفياً لشروط التعيين كافة.

يتوجب ابتداءً لممارسة العمل القضائي على أنواعه المختلفة أن يكون القاضي قد استوفى شروط التعيين كافة. وقد اختلفت النظم القانونية في العالم في طريقة تعيين القضاة.

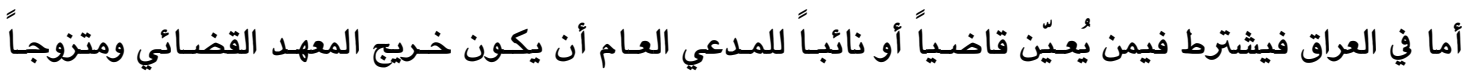

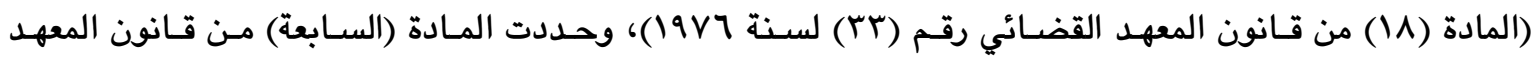
القضائي الشروط المطلوية للتعيين، لرفد القضاء بعناصر ذات كفاءة وتجرية في الاطلاع على تطبيقات أحكام القانون

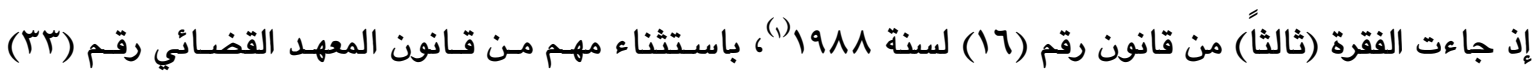

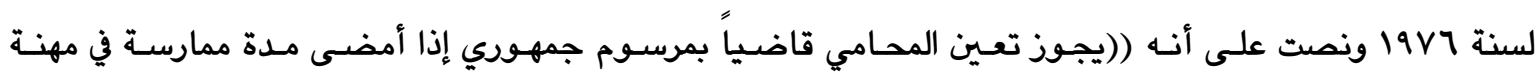
المحاماة لا تقل عن عشـر سـنوات، ولم يتجـاوذ عمـره الخامسـة والأريعـين استثناء مـن شـروط التخـرج مـن المعهد

$$
\text { القضائي). }
$$

يعين المتخرج من المعهد القضائي بمرسوم جمهوري بوظيفة قاض=إذا كان من المؤهلين للقضاء، ويوظيفة نائب مدع عام اذا كان من المؤهلين لهذه الوظيفة، بالراتـب والصنف والدرجـة الـتي يستحقها بموجب شـهادته وخدمتـهـ وممارسته والقدم الممنوح له بموجب أحكام هذا القـانون، وتعد مـدة الدراسـة في المعهد القضـائي للتعيين وتصديد الراتب بالنسبة لغير الموظف المادة (IV) من قانون المعهد القضائي. من التطبيقات القضائية فيما يتعلق بضرورة توفر شـروط التعيين في القاضـي مـا ذهبـت إليـه محكمـة التمييـز

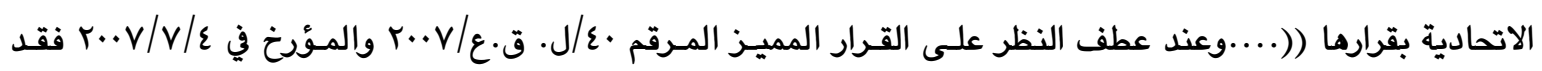
لوحظ بأنه صحيح وموافق للقانون حيث أن المميز عين قاضياً من قبـل قائد القـوات الأمريكيـة في محافظـــة بابـل في

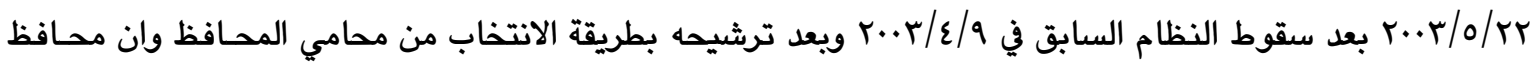

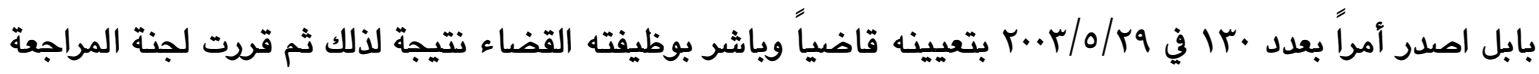

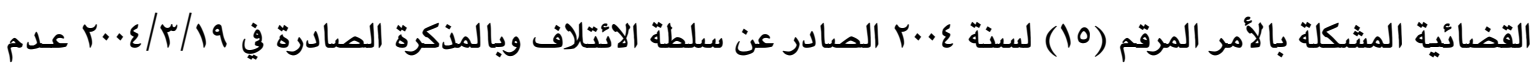
صلاحيته للتعيين..() (r) لذا فإن صدود الحكم من قاض لا تتوفر فيه شروط التعيين يجعل الحكم القضائي باطلاً لأسباب موضوعية.

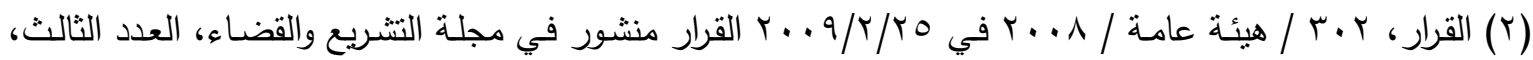


ثانياً: اختصاص (1) القاضي في إصدار الحكم.

لا يكفي أن يكون القاضي مستجمعاً لشروط التعيين ليصح حكمه بل يجب أن يكون القاضي مختصـاً بإصدار

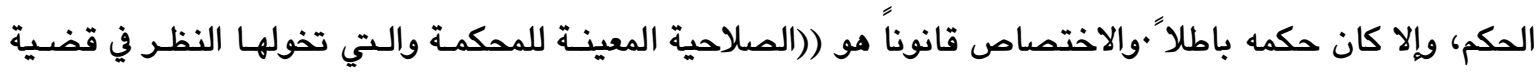
معينة)(r)

قد يعطي القانون الاختصاص لمحكمة وكما أنه يمكن أن يعطيها للجنة كما هي الحال بالنسبة للجـان القضـائية

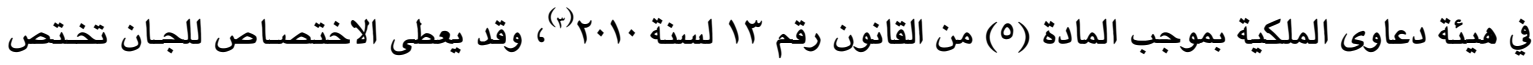
بالفصل في منازعات زراعية.

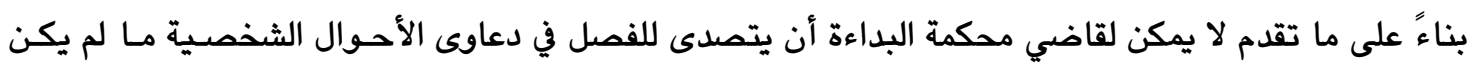
مخولاً بذلك، ولا يمكن لقاضي منطقياً أن ينظر في دعاوى المنطقة المجاورة.

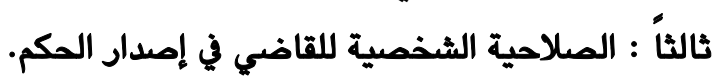
لبث الثقة في عدالة القضاء، ولإعطاء الخصوم ضمانات تكفل حقوقهم فقد نص قانون المرافعات المدنية العراقي

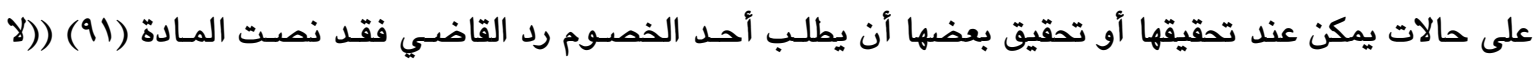
يجوز للقاضي نظر الدعوى في الأحوال الآتية:

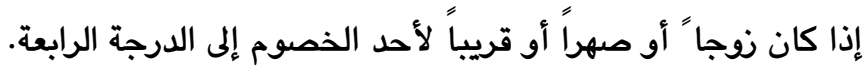

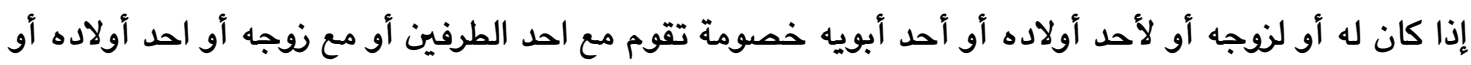
احد أبويه. إذا كان وكيلاً لأحد الخصوم أو وصياً عليه أو قيماً أو وارثـاً ظـاهراً لـه، أو كانـت لـه صـلة قرابـة أو مصـامرة

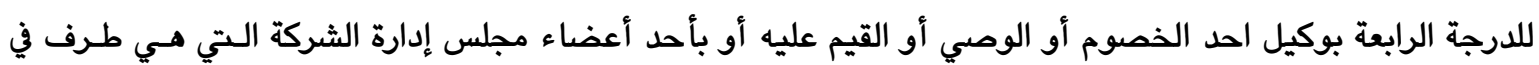
الدعوى أو احد مديريها. إذا كان له أو لزوجه أو لأصوله أو لأزواجهم أو لفروعه أو أزواجهم أو لمن يكون هو وكيلا عنه أو وصياً أو قيماً عليه مصلحة في الدعوى القائمة. إذا كان قد أفتى أو ترافع أحد الطرفين في الدعوى أو كان قد سبق له نظرها قاضياً أو خبيراً أو محكماً أو كان

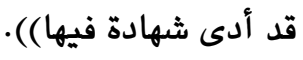

( (1) الاختصاص لغة: معناه التفضيل والانفراد، والتخصيص، والاختصاص والخصوصية والتخصيص : تفرد بعض الثيء بما لا يشاركه فيه الجملة وذلك خلاف العموم والتعمم والتعميم، قد خصـه بكذا يخصسه واختصسه يختصـه

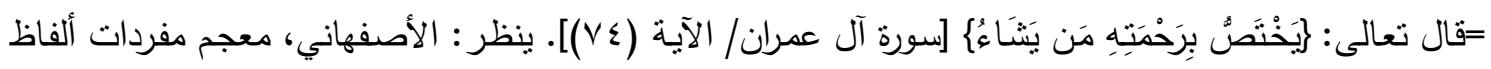

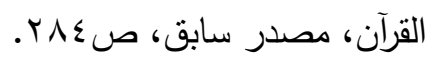

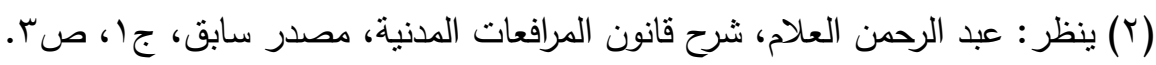

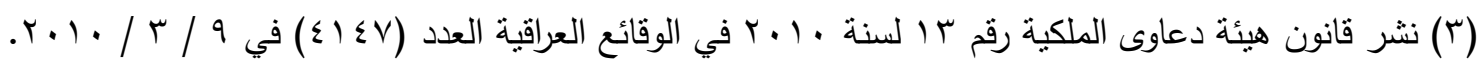
(§) ينظر : القاضي عواد حسين ياسين العبيدي: الاختصاص القضائي في منازعات الأراضي الزراعة، مكتبة الجيل

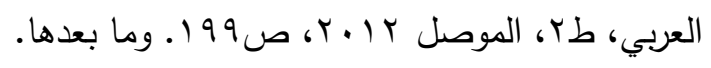


تعد المادة (19) بفقراتها الخمس الأسباب التي لا يجوز للقاضي إذا ما توفر سـبب مـن الأسـباب في شخصسه أن

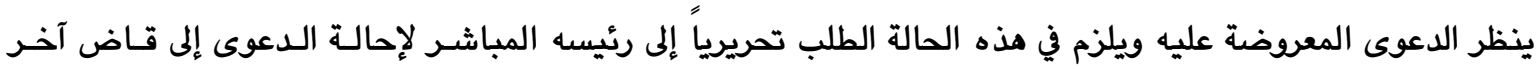
للنظر فيها.

ووضحت المادة (r9) الحكم الذي يترتب على عدم احتجاب القاضي عن نظر الدعوى في الحالات الواردة في المادة

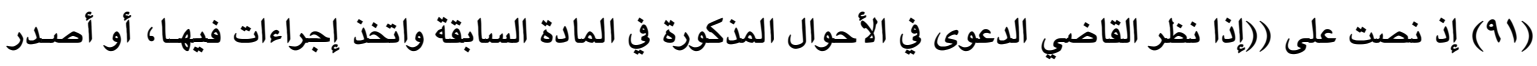

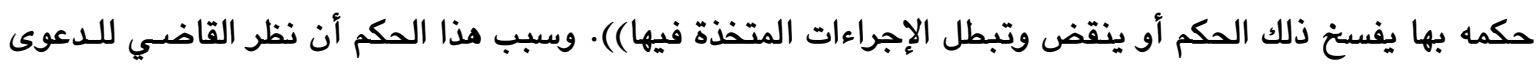
مع توفر سبب من الأسباب المنصوص عليها في المادة (91) يمنعه من رؤيتها يعد مخالفة صريحة لنص أمـر يتعلق

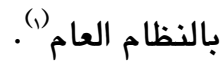
ونصت المادة (بوج) مرافعات على حـالات أخـرى يجـوز فيها رد القاضـي ((يجـوز رد القاضـي لأحـد الأسـباب

إذا كان أحد الطرفين مستخدماً عنده، أو كان هو قد اعتاد مؤاكلة أحد الطرفين أو مساكنته، أو كان قـد تلقىى منه هدية قبيل إقامة الدعوى أو بعدما. إذا كان بينه وبين أحد الطرفين عداوة أو صداقة يرجح معها عدم استطاعته الحكم بغير ميل، إذا كان قد أبدى

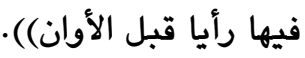

\section{البحثث ألثني

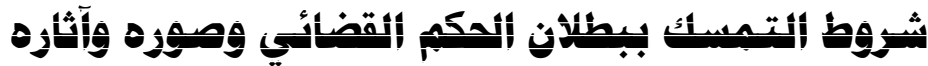

لابد أن يكون بطلان الحكم القضـائي بوجـود مصـلحة (عامـة، أو خاصـة) ممـا يقتضـي تـوفر شـروط للتمسـك

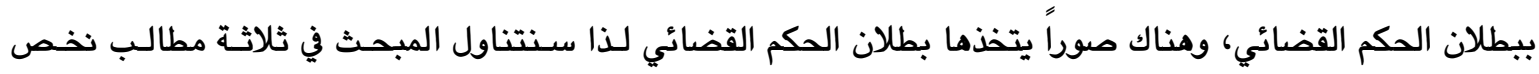
المطلب الاول لشروط التمسك ببطلان الحكم القضائي ونخص المطلب الثاني لصور التمسك ببطلان الحكم القضائي. ونخص المطلب الثالث لآثار الحكم القضائي الباطل.

\section{|}

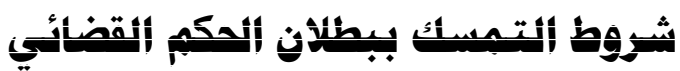

يتطلب الأخذ بالبطلان النسبي بالضرورة التمسك بهذا البطلان ولكن هل لكل شخص التمسـك بهذا البطلان أم هناك شروط خاصة للتمسك ببطلان الحكم القضائي وهناك شروط خاصة لابــ مـن توفرهـا فيمن يتمسـك بـبطلان الحكم القضائي لذا يمكن إرجاع هذه الشروط إلى شرطين أساسين سنتناولهما في فرعين:

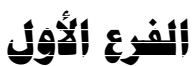

\section{وفمئو}

إن من البدهيات في قانون المرافعات المدنية أن قبول أي طلب أو دفع لابد من أن تكون لصاحبه فيه مصلحة قائمة يقرها القانون، فالدعوى بالأصل هي ((طلب شخص حقه من آخر أمام القضـاء)) المـادة (r) مرافعـات مدنيـة.

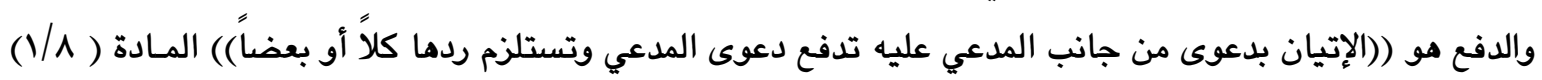


مرافعات مدنية. ويراعى في الدفع ما يراعى في المادة (^/^). في الدعوى، ومـن أهـم شـروط قبـول الدعوى هـو وجـود

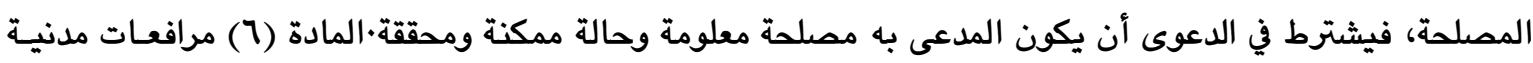
والمصلحة هي ((الفائدة العملية التي تعود على رافع الدعوى من الحكم لـه بطلبـه، فحيـث لا تعود مـن رفـع الدعوىى

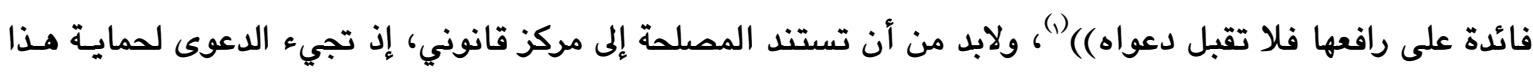

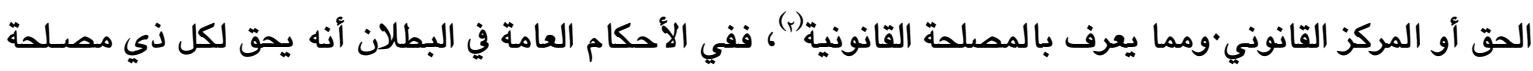
أن يتمسك بالبطلان. ((المادة (اع) من القانون المدني العراقي)).

\section{|أنف}

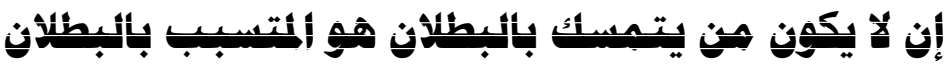

ليس لمن تسبب في البطلان أن يتمسك به، فسواء أكـان البطلان للإهمـال في التـزام وجـه الصـواب في مباشـرة

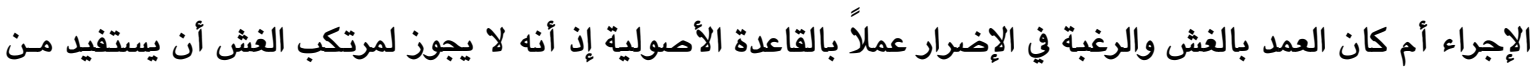
غشه، حتى ولو كان مضروراً من هذا التعيب، بل كان الإجراء مقرراً لمصلحته (r). ومن التطبيقات القضائية ذهبت محكمة التمييز الاتحادية في قرار لها إلى: ((....أما طعن المميزة بمدى مشروعية

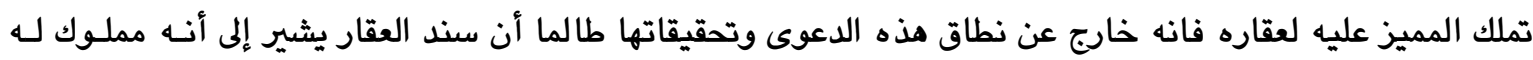
وإن ما مدون في السجلات العقارية والسندات الصـادرة بموجبها حجـة على النـاس كافـة ولا يطعن فيها الا بـالتزوير (م. ا/من قانون التسجيل العقاري النافذ) وان يكون الطاعن ذو مصلحة في الطعن عليه قرد تصديق الحكم المميز ورد

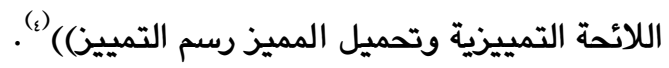
وذهبت محكمة التمييز في قرار لها ((...أن عقد الهبة عقد شـكلي لا يـتم إلا بتسـجيله بـدائرة التسجيل العقـاري

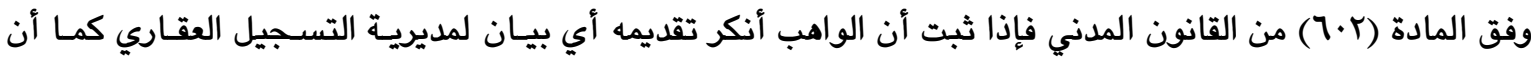
البيان المعزى تقديمه لا يحمل توقيع الواهب حتى تصح نسبته إليه قانوناً هذا بالإضافة إلى وجود حكم قضـائي لم

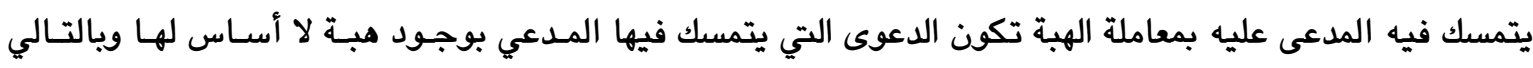
تردد... يتضح جلياً من قراءة أحكام القضاء العراقي أن التمسك ببطلان الحكم القضائي لابد من ان تتوفر فيـه شـروط خاصة ومن مذه الشروط وجود مصلحة، والا يكون من يتمسك بالبطلان هو المتسبب بالبطلان.

(1) ينظر عبد الرحمن العلام، شرح قانون المرافعات المدنية رقم rم لسنة 979 19، طب، ج)، الناشر العاتك لصناعة

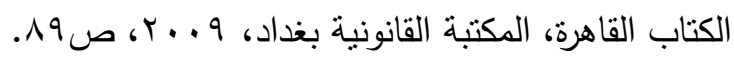

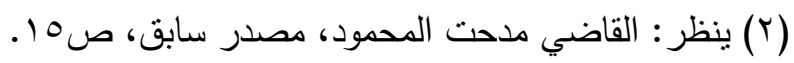

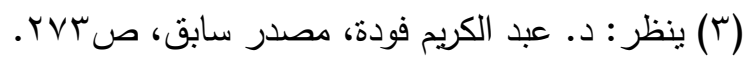

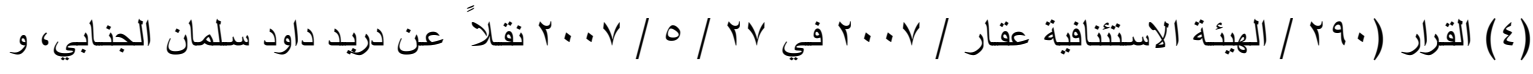
المحامي باسم محمد علي الخفاجي، القرار منشور في كتاب المبادئ القانونية في قضاء محكمة التمييز الاتحادية،

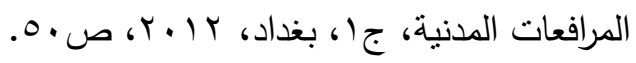

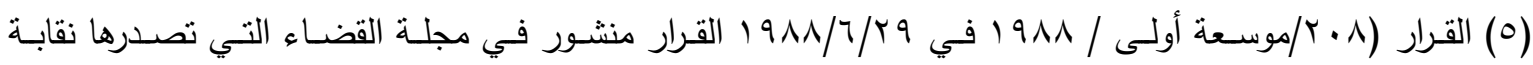

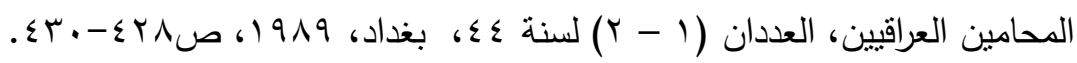




\section{itifi

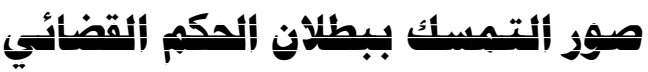

يمكن ارجاع صور التمسك ببطلان الحكم القضائي إلى صورتين سنتناولهما في فرعين نخص الفرع الأول للتمسك ببطلان الحكم القضائي في صورة دفع ونخص الفرع الثاني للتمسك ببطلان الحكم القضائي في صورة دعوى.

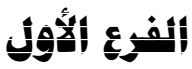

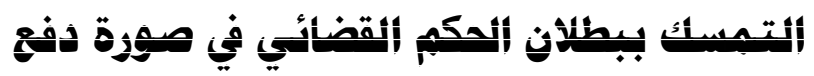

عرفت المادة (1/1) من قانون المرافعات المدنية الدفع بأنه : (هو الإتيان بدعوى من جانب المدعى عليه، تدفع

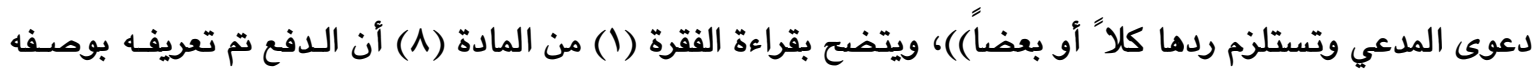

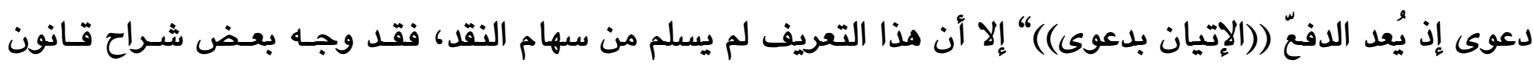
المرافعات المدنية انتقادات قوية لهذا التعريف الذي وصف (الدفع) بكونه (دعوى).

تلخصت حجج أصحاب هذا الاتجاه بأن الدفع لا يقتصر مفهومه على الدعوى وإنما هـو في حقيقته وسـيلة يلجـأ إليها المدعي عليه للرد على طلبات المدعي سواء أكانت موجهة لموضوع الحق المدعي به، أم يتعلق بالخصـومة، أم بالإجراءات القضائية. وقالوا: الدفع هو كل ما يجيب به الخصم على دعوى خصمه (1).

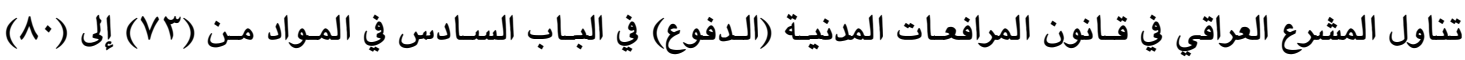
والدفوع كما عرفها فقه المرافعات المدنية يمكن تصنيفها على ثلاثة أنواع هي (r): النوع الأرل/ الدفوع الموضوعية. هي الوسائل التي يلجأ إليها المدعى عليه ليثبت أن دعوى خصمه على أساس غير قانوني، وهي دفـوع تتعلق

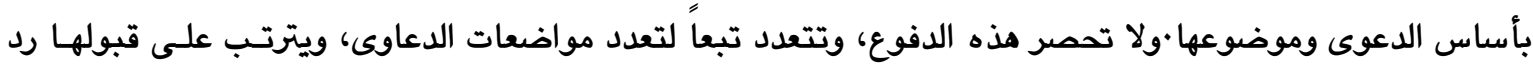
دعوى المدعي كلاً أو جزءً ومن أمثلتها الدفع بانقضاء الدين المطالب به في الدعوى بالوفاء أو الإبراء أو المقاصة. ودهاء النوع الثاني/ الدفوع الشكلية. يقصد بها الدفوع التي يطعن فيها الخصم بعدم قانونية إجراءات الدعوى قبـل الدخول في أساسـها وموضـوعها، وهي أما دفوع لا تتعلق بالنظام العام ويقتصر حق التمسك بها على الخصم، ومثلها الدفع بعدم اختصـاص المحكمـة

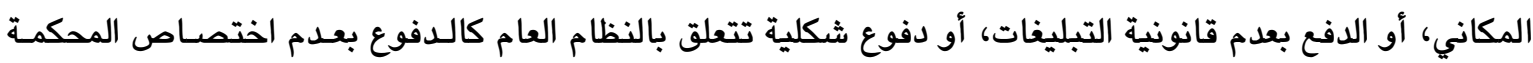
الوظيفي أو النوعي أو القيمي، وتقضي به المحكمة من تلقاء نفسها ولو لم يدفع به الخصوم.

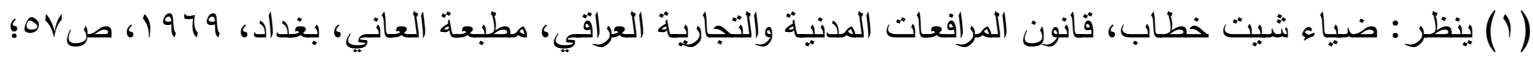

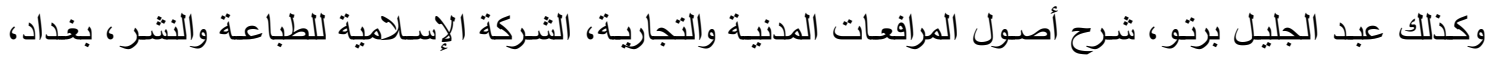
(190V

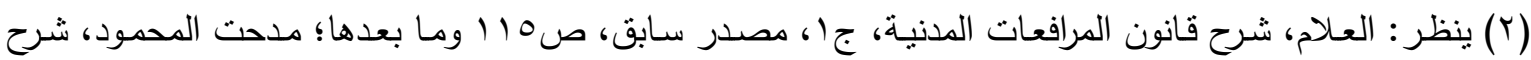
قانون المرافعات المدنية، مصدر سابق، صهرحلـ 
النوع الثالث/ الدفوع بعدم قبول الدعوى.

يتضمن هذا الدفع رد الدعوى لعدم توفر الشروط العامـة فيها كالدفوع بعدم توجـه الخصـومة، والـدفع بسـبق الفصل في الدعوى، والدفع بالتقادم، والدفع بانقضاء المدة المحددة للطعن بـالاعتراض أو بالاستئناف. وتمثل هـذه

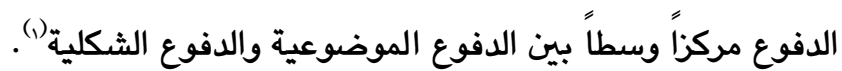

\section{الزفوع إلثاني}

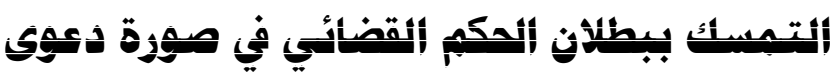

عرفت المادة (r) من قانون المرافعات المدنية الدعوى بأنها: ((طلب شخص حقه من آخر أمـام القضـاء)) ومـن تحليل مذه المادة تتضح عناصر الدعوى وهي: ((أ- طلب، ب- وان يقدم الطلب إلى القضاء ويالتالي تخرج الطلبـات

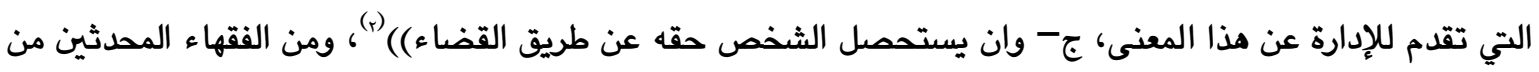

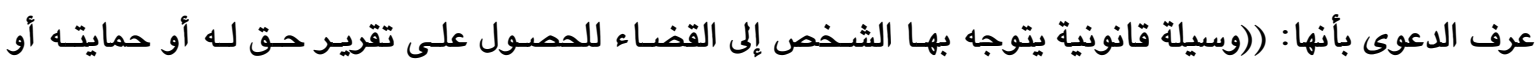

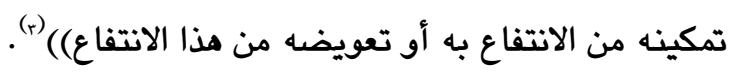

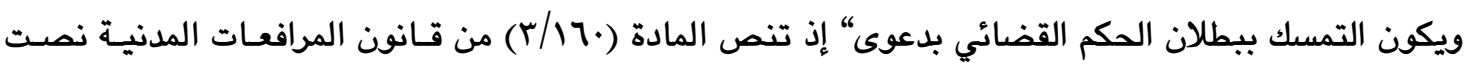

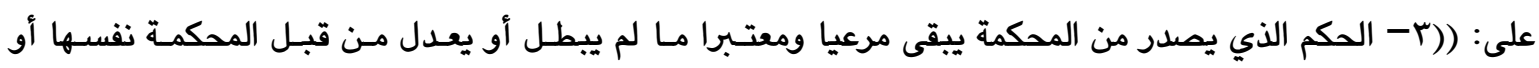

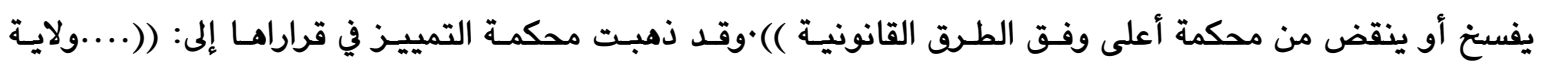

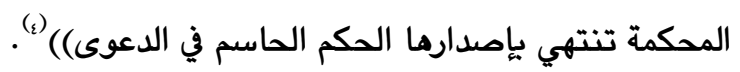

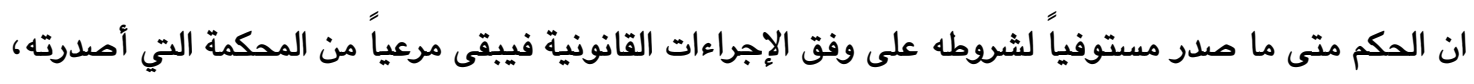

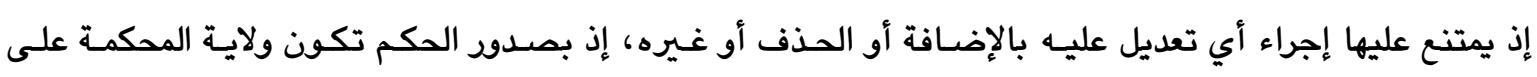

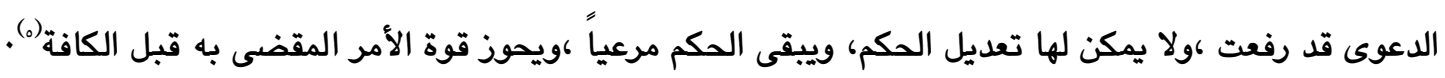

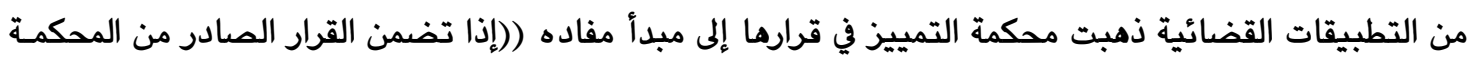

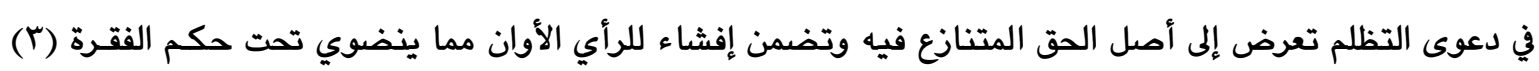

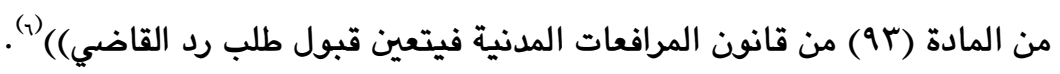
يجب التقيد بالأسباب الموضوعية لبطلان الحكم القضائي عند إصدار الحكم القضائي وإلا فان الحكم القضـائي

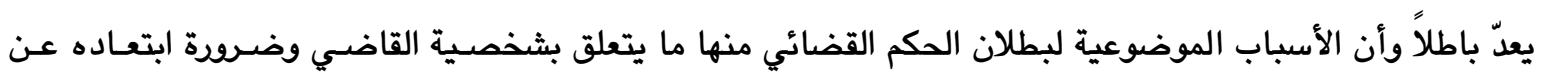

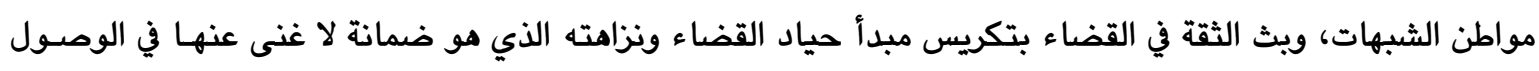
إلى حكم عادل.

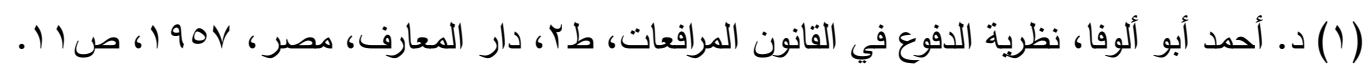

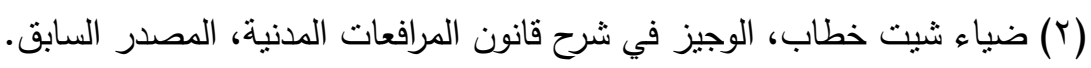

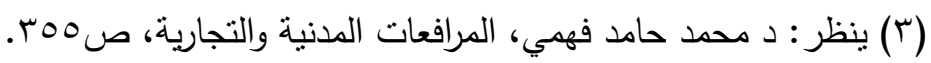

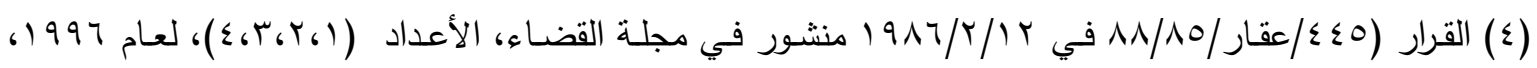

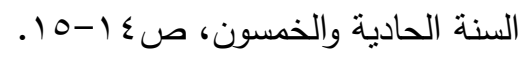

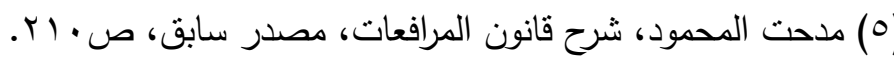

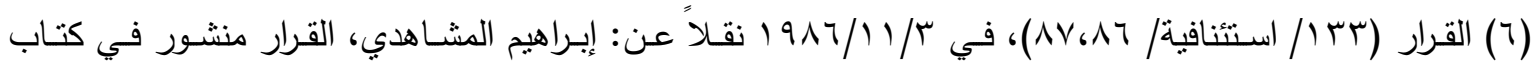

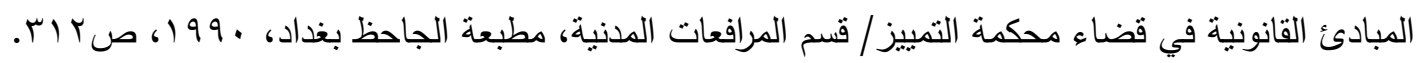




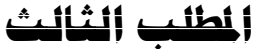

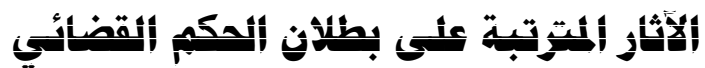

لقد سبق القول أن أسباب بطلان الحكم القضائي هي (شكلية وموضوعية) لذا نحاول بيان الآثار المترتبـة على بطلان الحكم القضائي بالتعرف على تلك الآثار بحسب التقسيم الذي تم اعتماده مما يتوجب تقسيم هـذا المطلب إلى فرعين نخص الفرع الأول لأثر بطلان الحكم القضائي المترتب على تخلف الأسباب الشكلية ونخص الفرع الثاني لأثر بطلان الحكم القضائي المترتب على تخلف الأسباب الموضوعية الخاصة ببطلان الحكم القضائي.

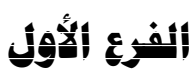

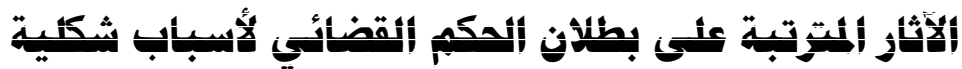

لابد من ان تكون فلسفة التقاضي واضحة المعالم، قليلة الإجراءات تهجر الشـكل الجامـد، ولا تلـوذ بالشـكل إلا مضطرة تصون به الحق، وتدفع به الباطل ما وجدت إلى ذلك سبيلاً، مما يتماشى مع احد أهداف قانون الإثبات رقم

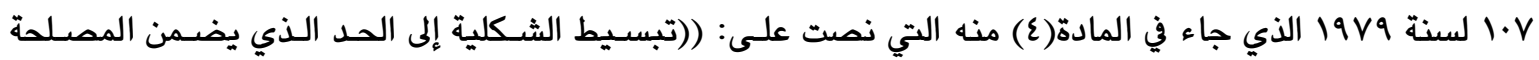
العامة ولا يؤدي إلى التفريط بأصل الحق المتنازع فيه)) فمواطن العدل بمضـمونه وفحـواه وان التشـريعات الإجرائيـة

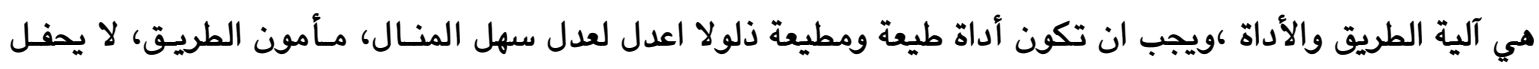

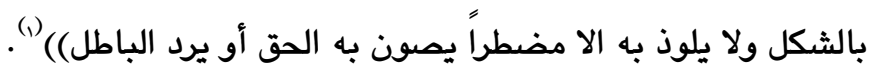

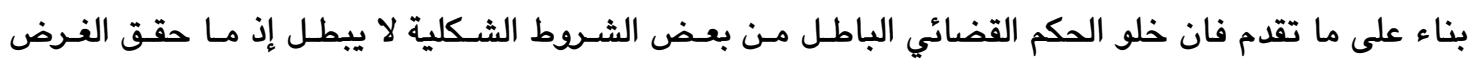
المنشود وهو تحقيق العدالة وإعادة الحق إلى أهله، ومن ثم يمكن معالجة هذا الخلل في أحيان معينة أما في حالة وجـود

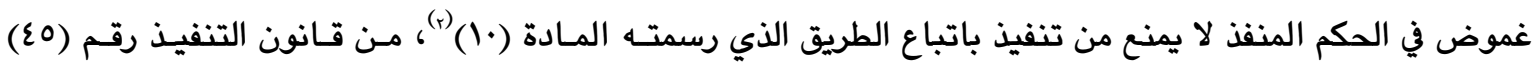
لسنة • 191 المعدل وان كان الأمر لا يخلو من إثكالات عملية جمة في الواقع العلمي (r).

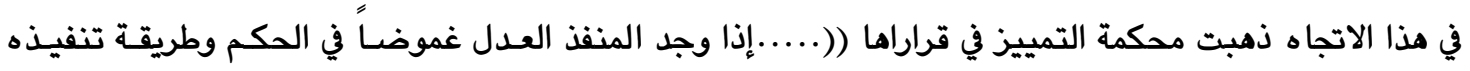

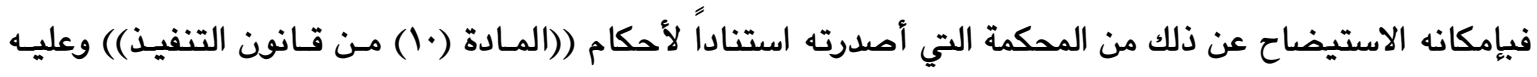
قرر نقض القرار المميز وإعادة الاضبارة التنفيذية إلى مديرية تنفيذ الكرادة للسير فيها وفق ما تقدم .......) وصدر

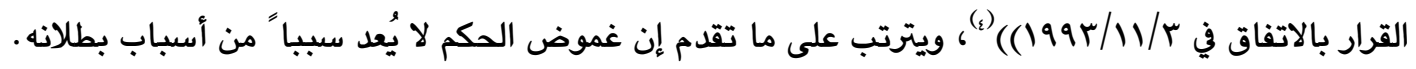

(1) ينظر : د. آدم وهيب النداوي، فلسفة إجراءات التقاضي في قانون المرافعات المدنية، طا، مطبعة العليم العالي،

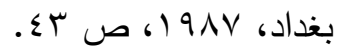

(r) نصت المادة (• () من قانون التتفيذ على (للمنفذ العدل ان يسنوضح من المحكمة التي أصدرت الحكم عما ورد

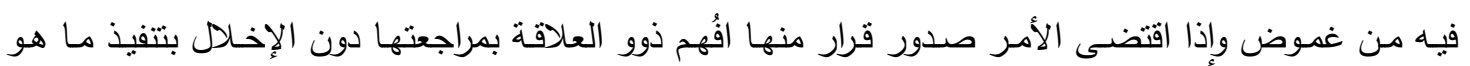

$$
\text { واضح من الحكم الواجب التتفيذ)). }
$$

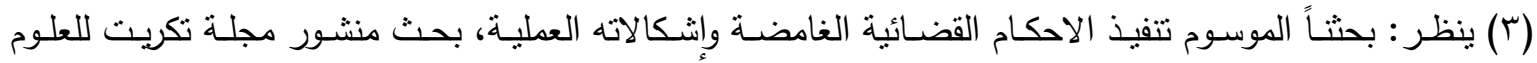

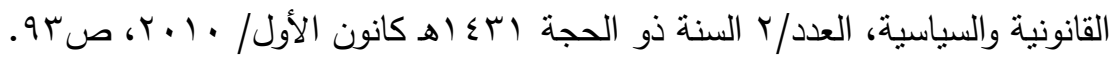

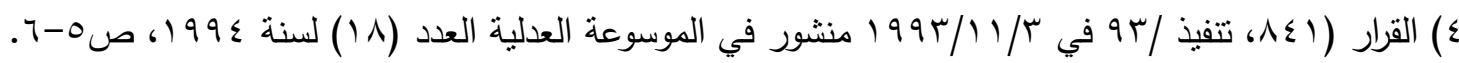


أما إذا كان بطلان الحكم القضائي لسبب شكلي لا يمكن إصلاحه فهنا يتوجب إبطال الحكم والإجراءات المتخذة

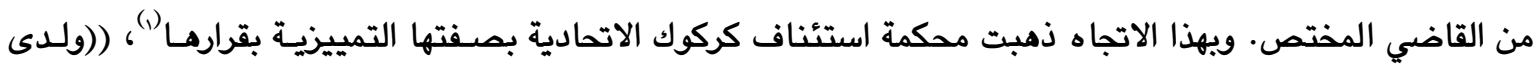
عطف النظر على القرار المميز الصادر من قاضي البداءة بصفته المنفذ العدل فقد وجد أنـه غـير صـيح ويخـالف أحكام القانون ذلك لصدروه دون ملاحظة أن محضر وضع اليد لم يوقع من قبل قاضي البداءة بصفته المنفذ العدل ويذلك فانه يعتبر باطلاً وان الإجراءات اللاحقة تعتبر باطلة هي الأخرى لذا نقض القرار المميز وإعادة الإضبارة تعتـبر

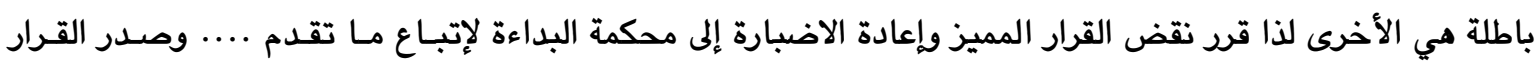

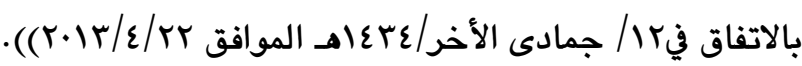

ذهبت محكمة التمييز الاتحادية في قرارها إلى: (...... ولدى عطف النظر على الحكم المميز وجد أنه غير صحيح

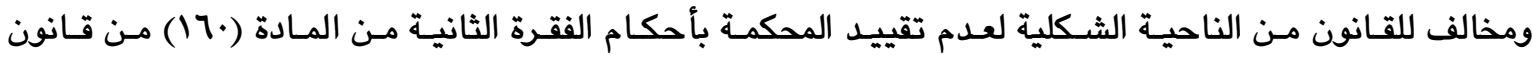
المرافعات المدنية إذ لم يتبين في مسودة الحكم المميز اسـم العضـو المخـالف ولم يدون مخالفتهـه بعد صـدور الحكم

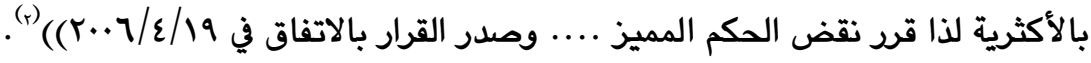
ويتطلب بطلان الحكم القضائي لأسباب شكلية تصحيح الحكم وأعماله ما وجد إلى ذلك سبيلاً.

\section{ألفرع إلثاني}

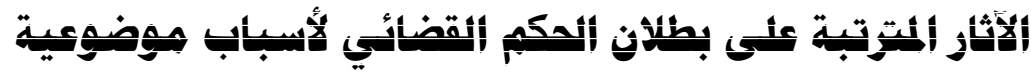

يُعدّ بطلان الحكم القضائي لمخالفته للأسباب الموضوعية من حيث الاختصاص الوظيفي أو صلاحيته القاضي

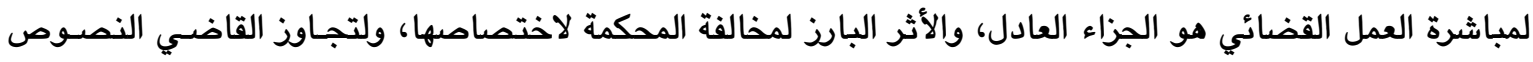

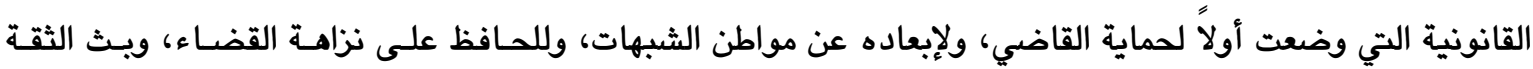
فيه، واطمئنان الأفراد على حقوقهم. من التطبيقات القضائية ذهبت محكمة التمييز في قرارها إلى: (....... ولدى عطف النظر على القرار المميز وجد بالنظر للأسباب التي استند اليها جاء موافقاً للقانون لان ما نسب للقاضي / المميز عليه هو انابته المعاون القضـائي في محكمة الأحوال الشخصية في الاعظمية لإجراء الكشف على البيت الشرعي اثناء نظره إحدى الدعاوى وعدم قيامـه هو بإجراء الكثف حسبما يتطلبه القانون وان ما نسب للقاضي المذكور لا يشكل مخالفة لواجباته المنصوص عليها

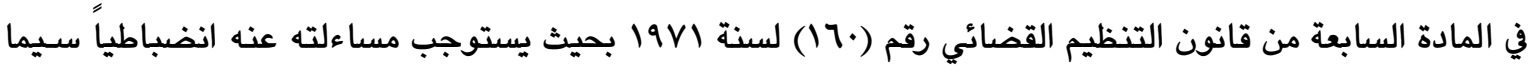

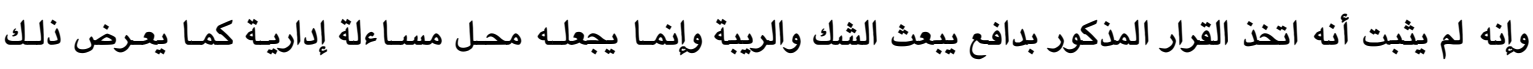

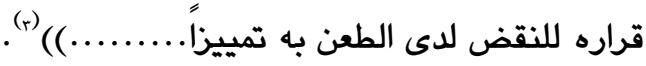

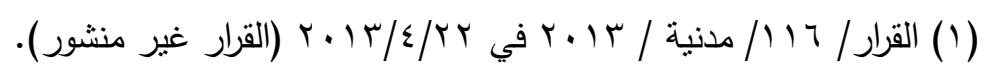

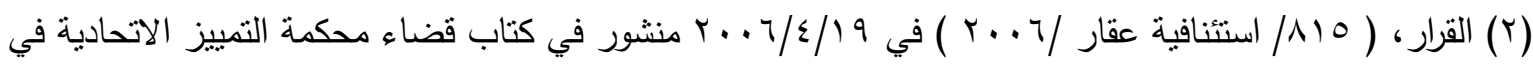

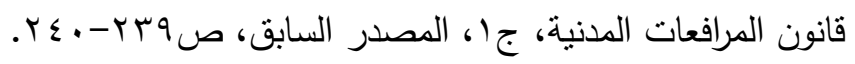

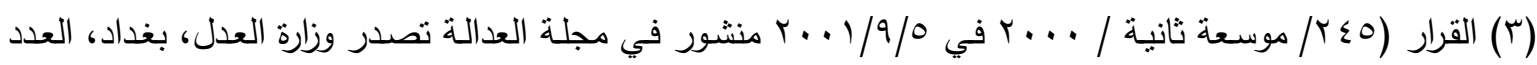

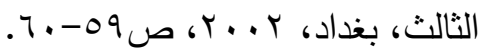


ذهبت محكمة التمييز بقرار آخر لها (1)، إلى: ((.... لا يجوز لقاضي الموضوع اتخاذ قـرار على عريضــة الدعوى برفض الطلب لعدم الاختصاص المكاني، وإنما يترتب على المحكمة تسجيل الدعوى وتبليــ الطـرفين بيـوم المرافعـة فان دفع المدعى عليه بعدم اختصاص المحكمة المكاني تنظـر في مـذا الدفع وتصـدر القـرار المقتضـي .... وصـدر

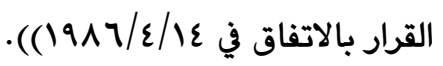

هنا قد يسأل سائل ما هو مصير القرار المتخذ من دون إكمال إجراءات التبليخ؟ أجابت محكمة التمييز الاتحادية

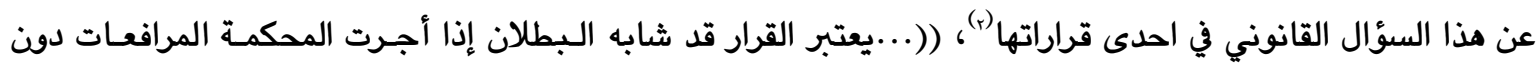

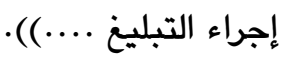
من التطبيقات القضائية التي تتعلق باختصاص المحكمة الوظيفي ذهبت محكمة التمييز الاتحادية بقرار لها إلى: (.........(ولدى عطف النظر على الحكم المميز فقد وجد أنه غير صحيح ومخالف للقانون حيث أن قـرار مجلس قيـادة الثورة المنحل المرقم (1) (1) لسنة ال1911 تضمن إطفاء الحقوق التصرفية من قبل اللجنة المشكلة بموجبه وأن قـرار

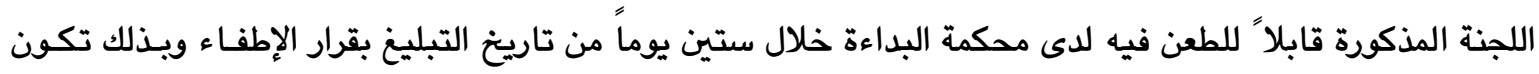

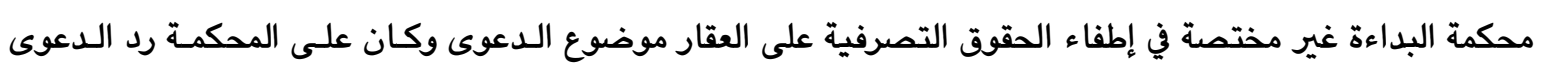

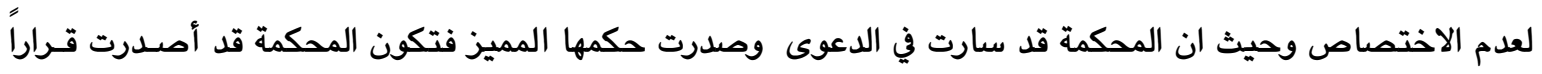

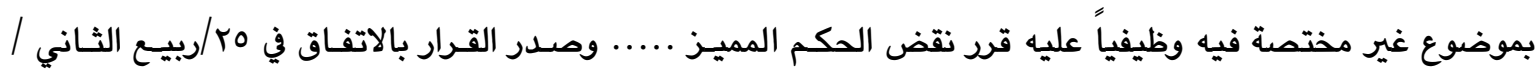

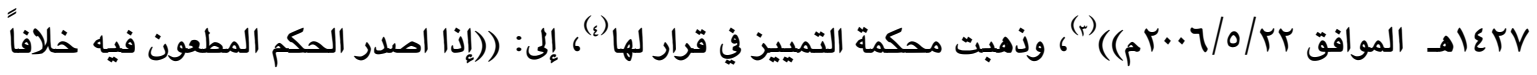
لقواعد اختصاص المحاكم التي هي من النظام العام يكون قد احتوى على خرق للقانون لذا يقبل الطعن فيه لمصلحة

القانون)(c)

نخلص مما تقدم إن القضاء العراقي اتجه إلى بطلان الاحكام القضائية عند مخالفتها للنظـام العام على الرغم

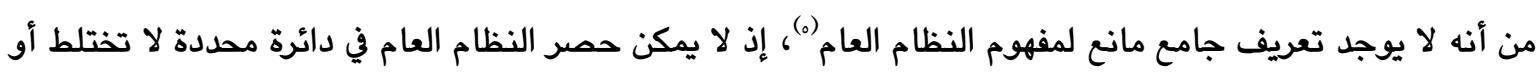

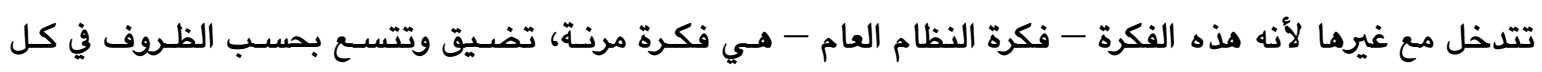

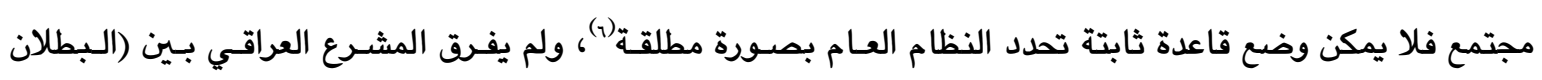

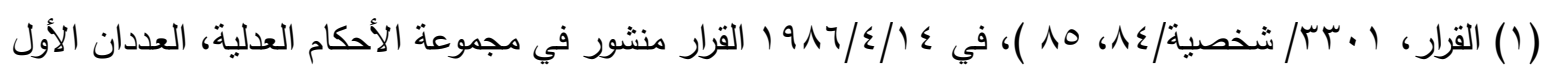

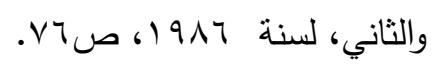

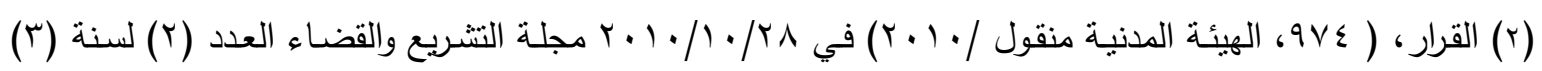
ror ص. TH

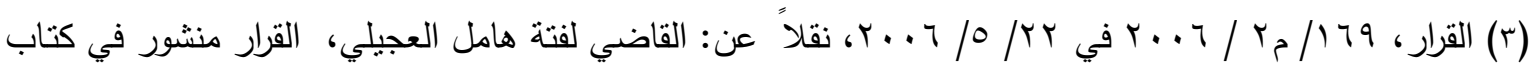

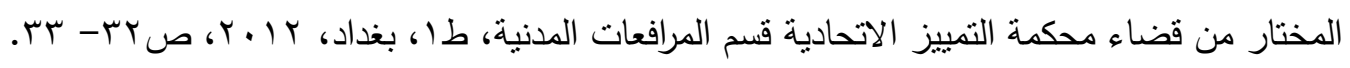

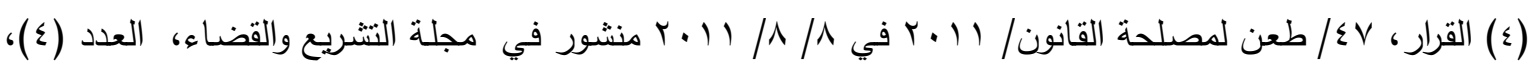

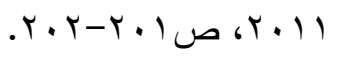
(0) ينظر : د. عبد المجيد الحكيم، الموجز في شرح القانون المدني، طه، ج)، مصادر الالتزام مطبعة نديم، بغداد،

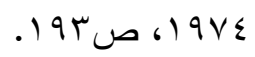
(†) ينظر : د. عبد الرزاق أحمد السنهوري، الوسيط في شرح القاني المدني الجديد، ط؟، المجلد الأول، نظرية الالتزام

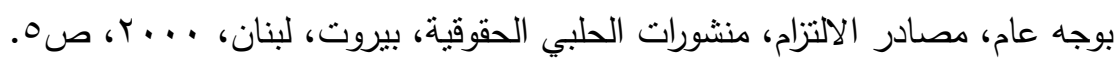


المطلق أو الوجوبي) البطلان المتعلق بالنظام العام والبطلان (النسبي او الجوازي) البطلان المتعلق بالمصلحة العامـة

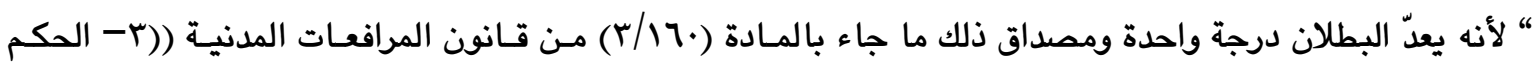

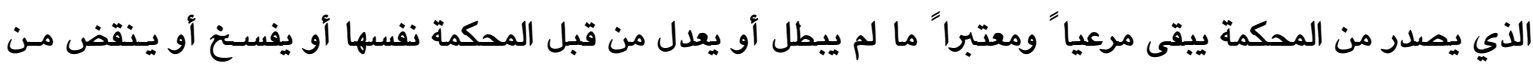
محكمة أعلى منها وفق الطرق القانونية)) فقد ورد لفظ الإبطال مطلقاً.

ا. لم يكن تعريف الحكم القضائي الباطل محل اتفاق بـين فقهاء القـانون، ولا تبتعد التعريفـات الـي وضـعت

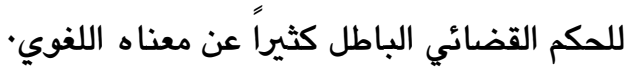
r. لقد تبنى الفقه القانوني التقسيم الثنائي للبطلان ((نسبي ومطلق)) وسعى الفقهاء جاهـدين إلى التقليـل مـن

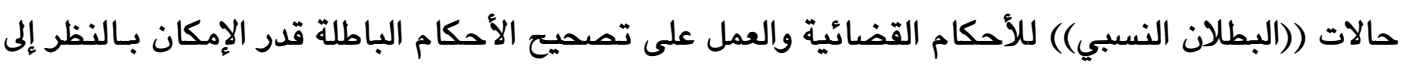

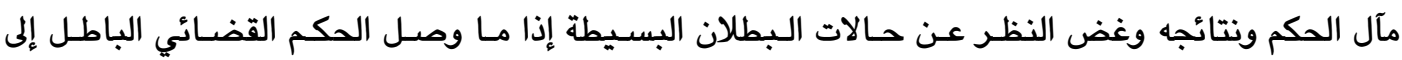
مبتغاه في إحقاق الحق.

r. يمكن تصنيف أسباب بطلان الحكم القضـائي إلى صـنفين ((أسـباب شـكلية)) و(أسـباب موضـوعية)) إذ

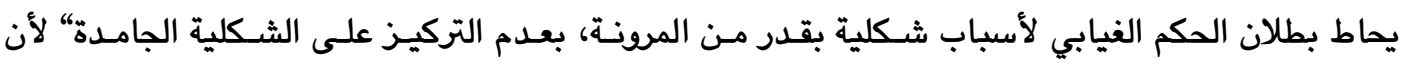

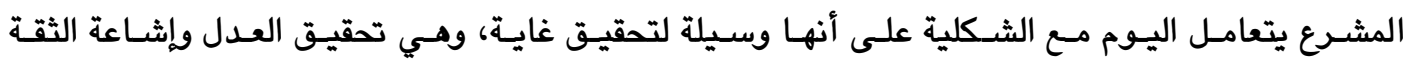
والاطمئنان في القضاء، لذا فانه جعلها تتسم بسمتين لازمتين لتحقيـق هـا الهدف السـامي وهمـا بالمرونـة والنظر إليها على أنها وسيلة وليست غاية بحد ذاتها. ع. للقضاء العراقي بصمة واضحة، وكلمة مسموعة، وصولة مشهودة في الوقوف بحزم حيال التهاون في مراعـاة

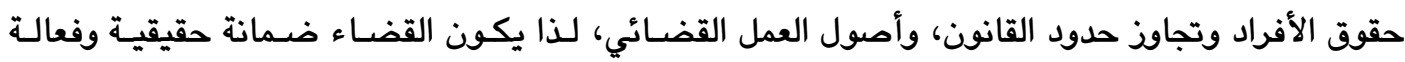

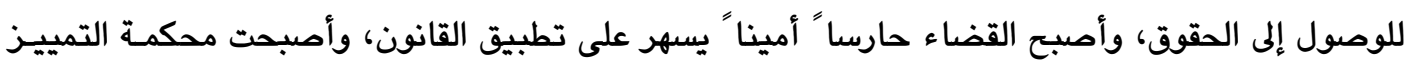
الاتحادية تباشر رقابتها على المحاكم من دون ملل أو كلل. ثانياً: التوصيات

I. ضرورة إعادة دراسة المواد الخاصة ببطلان الحكم القضائي وتقنينها بشكل جديد يعمل على إعطـاء نظريـة واضحة لبطلان الأحكام القضائية في قانون المرافعات المدنية العراقي ببيان حالات البطلان وأنواعه والآثار المترتبة على كل نوع. r. حث القضاء على التوسيع في تصحيح الأحكام القضائية الباطلة بطلاناً نسبياً ما وجد إلى ذلك سبيلاً بالنظر إلى مآل الأحكام ونتائجها وتجاوذ ما اعتراها من عيب بسيط إذا ما حقق الحكم القضـائي الغايـة المنشـودة منه وهي تحقيق العدالة. r. ضرورة تبنى حكمة المشرع العراقي في قانون الإثبات وتحقيق أهم أهدافـه الـتي ضـمنها في المـادة (ع) مـن

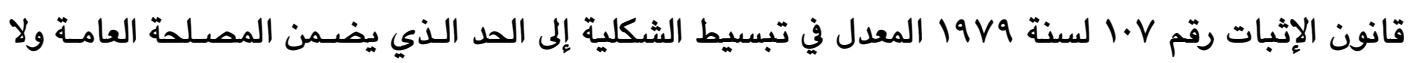

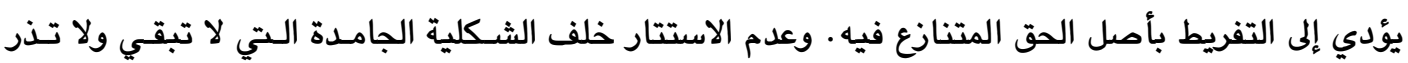
للعمل القضائي أية مرونة وترهق كامل البشر. 
إن هذه المحصلة الموجزة هي اجتهادات شخصية تقبـل الخطـأ والصـواب والمجتهد يجتهـد فيصـيب أو يخطـأ

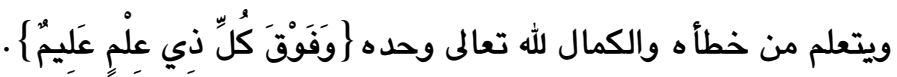

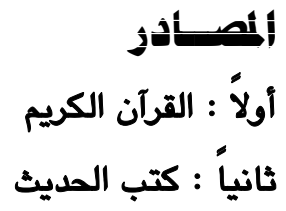

ا. الإمام أبو داود سليمان بن الأشعث السجستاني الأزدي، سـنن أبي داود، طا، جr، المجلد الثالث، دار المعرفـة

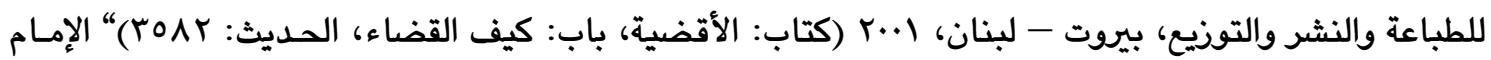
أبو عيسى محمد بن عيسى بن سورة بن موسى الترمذي، الجامع الصديح (سنن الترمذي)، تدقيق أحمـد زهـوة

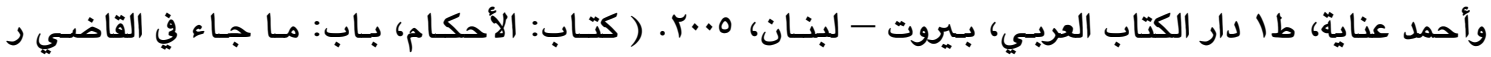

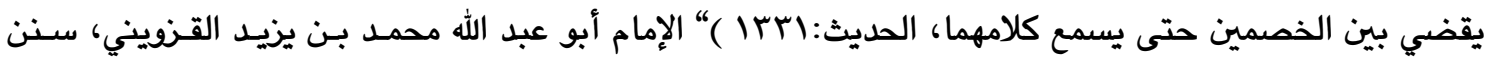

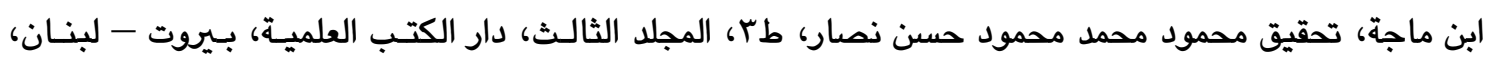

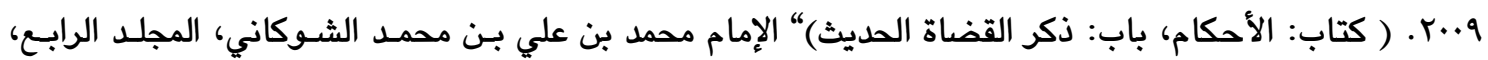

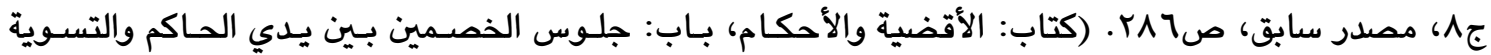
بينهما، الحديث:140)" الإمام محمد بن إسماعيل الأمير الصنعاني، سبل السلام شرح بلوغ المرام من جمع أدلة

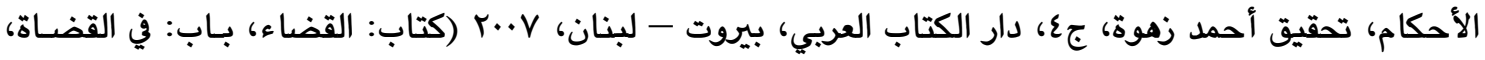

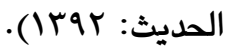

r. سليمان بن الأشعث (المتوفى Yroمـ)، سـنن أبي داود، جr، تحقيـق محمد محي الدين عبد الحميد، مطبعة مصطفى محمد، القاهرة. ثالثاً : كتب الفقه الإسلامي ا. العلامة برهان الدين ابو الوفاء إبراهيم شمس الدين محمد بن فرحون اليعمري المالكي، تبصـرة الحكام في أصسول الاقضية ومناهج الأحكام، خرج احاديته وعلق عليه وكتب حواشـيه، الشـيخ جمـال مرعشـلي، جـزءين في مجلد

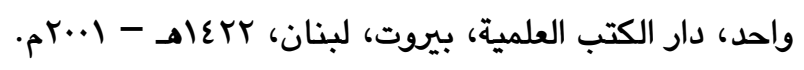

r. د. عبد العزيز علي سلمان الماضي، القضـاء والحكم على الغائب في الفقـه الإسـلامي، طا، دار الفتح للدراســات

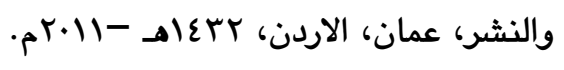

r. د. عدنان بن محمد بن عتيق الدقيلان، الدعوى القضائية في الفقه الإسلامي، طا، دار ابن الجوزي للنشر والتوزيع،

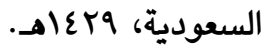
ع. علي بن أحمد بن سعيد الأندلسي، المتوفى (70 كــ)، المعروف بابن حـزم، المحلى، الطباعـة المنيريـة، القـاهرة،

๑. محمد الحبيب التجكاني، النظرية العامة للقضاء والاثبـات في الشـريعة الاسـلامية مقارنـات بالقـانون الوضـعي، دار النشر المغربية، دار الشؤون الثقافية العامة، آفاق عربية، نشر مشترك، بدون طبعة، وتاريخ طبع. T. د. محمد الزجيلي، التنظيم القضائي في الفقه الإسلامي، دراسة مقارنة، طY، دار الفكر، دمثق، سـوريا، بrعاهـ 
V. د.محمد نعيم ياسـين، نظريـة الـدعوى بـين الشـريعة الإسـلامية وقـانون المرافعـات المدنيـة والتجاريـة، طـا، دار

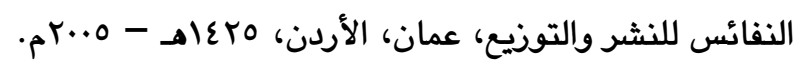

^. د. محي ملال السرحان، النظرية العامة للقضاء في الإسلام، مركـز البحـوث والدراسـات الإسـلامية، ديـوان الوقـف

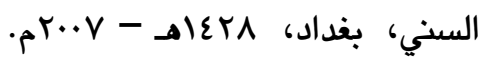

$$
\begin{aligned}
& \text { رابعاء": الكتب القانونية }
\end{aligned}
$$

ו. د. أحمد أبو الوفا، المرافعات المدنية والتجارية، دار النهضة مصر، 19У0. ، المستحدث في القانون المرافعات الجديد وقانون الإثبـات، منشـأة المعـارف، طا، الإسـكندرية

نظرية الأحكام في قانون المرافعات المدنية، منشأة المعارف ط7، الإسكندرية مصر، 1919. $\cdot r$ ع. د. آدم وهيب النداوي، فلسفة إجراءات التقاضي في قانون المرافعات المدنية، مطبعة التعليم العـالي، طا، بغداد

0. المستشار أنور طلبة، بطلان الأحكام وانعدامها، المكتب الجامعي الحديث، الإسكندرية، مصر، rا.ب.

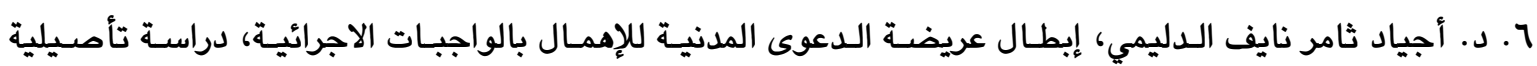
تحليلية مقارنة، طا، بيت الحكمة، بغداد، rا.r.

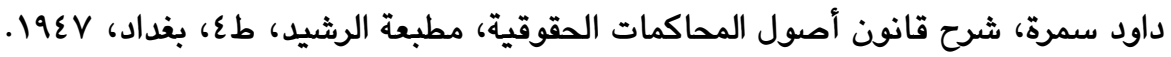

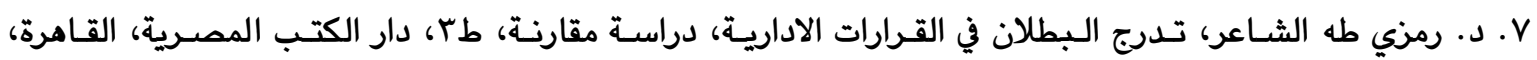

1. القاضي شهاب أحمد ياسين / انعدام الاحكام، طا، شركة العاتـك لصـناعة الكتـاب، القـاهرة، المكتبـة القانونيـة،

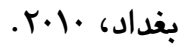

9 9. ضياء شيت خطاب، الوجيز في شرح قانون المرافعات المدنية، مطبعة العاني، بغداد، 19Vr. فن القضاء، معهد البحوث والدراسات العربية، بغداد، ع.عاهـ-ع^191. $\cdot 1$.

شرح قانون المرافعات المدنية والتجارية العراقي، مطبعة العاني، بغداد، 1979.

r r ا. عبد الجليل برتو، شرح أصول المرافعات المدنية والتجارية الشركة الإسلامية للطباعة والنشر، بغداد، 190V. זا. د. عبد الرزاق السنهوري، شرح القانون المدني الجديد المجلد الأول، نظرية الالتزام بوجه عام، مصادر الالتـزام،

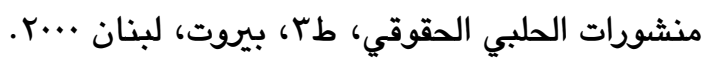

عا. د. عبد المجيد الحكيم، الموجز في شرح القانون المدني، مصادر الالتزام، جا، طه، مطبعة نديم، بغداد، عV19.

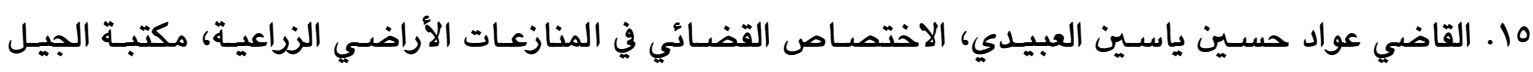

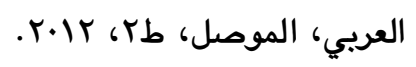

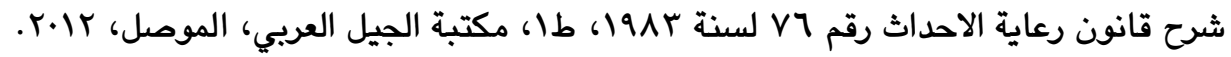
.17 VI القاضي الدكتور عبد الغفور محمد اسماعيل البياتي، الاصول والثوابت في القضـاء الاسـلامي وآثرهـا في القـوانين

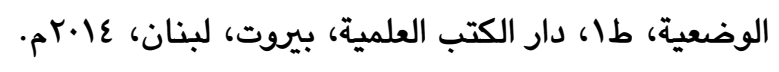


11. عبد الرحمن العلام، شرح قانون المرافعات المدنية رقم ؟ N لسنة 1979 مـع المبـادئ القانونيـة لقـرارات محكمـة تمييز العراق مرتبة على مواد القانون، طץ، جr، الناشر العاتك لصناعة الكتاب، القاهرة، المكتبة الوطنية، بغداد،

شرح قانون المرافعات المدنية رقم 1 لسنة 1979 المعدل، طץ، جا، الناشر العاتك لصناعة .19

الكتاب القاهرة، المكتبة القانونية بغداد، و..r.

.r. القاضي مدحت المحمود، شرح قانون المرافعات المدنية، طا، دراسة تطبيقية، بغداد، ه..r.

ا M. د. محمد سعيد عبد الرحمن، الحكم القضائي أركانه وقواعد إصداره، دراسة تأصيلية تحليلية تطبيقيـة مقارنـة، دار الفكر الجامعي، الاسكندرية، م.•r.

r. المحامي محمد عبد الرحيم عنبر، المحامي فريد محمد عنبر، الوجيز في نظرية البطلان، دراسة فقهية مقارنـة بـين

تشريعات الدول العربية والشريعة الاسلامية، طا، بدون مكان نشر، 1911.

ب. . د. يوسف محمد المصاروة، تسبيب الأحكام وفـق قـانون أصـول المحاكمـات المدنيـة، طج، دار الثقافـة للنشـر

$$
\begin{aligned}
& \text { والتوزيع، عمان، الأردن، البعاهـ -..... } \\
& \text { خامساً: رسائل الماجستير }
\end{aligned}
$$

ا. صدام خزعل يحيـى، النظـام القـانوني للحكم الباطـل، دراسـة مقارنـة: رسـالة ماجستيـ، مقدمـة إلى كليـة

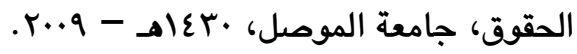

سادساً: البحوث المنشورة جامة أموهل

1. أحمد أبو ألوفا، تسبيب الأحكام، بحث منشـور في مجلـة الحقوق للبحـوث القانونيـة الاقتصـادية، العـددان

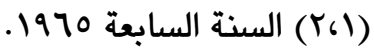

r. ضياء شيت خطاب، الرأي المخالف في الأحكام القضـائية، بحث منشـور في مجلـة القضـاء تصـدرها نقابـة

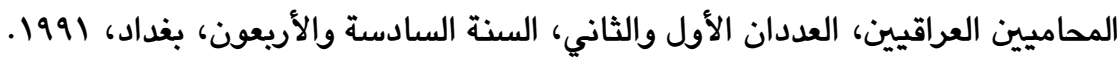

r. القاضي عواد حسين ياسين العبيدي، تنفيذ الأحكام القضائية الغامضة وإثكالاته العلمية، بحث منشـور في

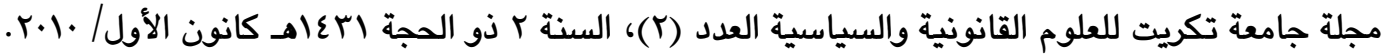
سابعا": البحوث المنشورة عن الانترنيت (الشبكة العنكبوتية)

ا. مصطفى محمد عبود القره غولي، الحكم المعدوم والحكم الباطلـل، مقـال منشـور على الموقـع آخـر زيـارة

$(r .1 r / 11 / 10)$

http://www.uobabylon.edu.iq/uobColeges/service_showrest.aspx?f...

$$
\text { r. ينظر: احمد أبو الزين، الحكم المعدوم بين الفقه الاجتهاد، بحث متاح على الموقع }
$$

http:// www. Justice - lawhome. com/vb/showthresd.php? t = 21761

$$
\begin{aligned}
& \text { أخر زيارة 10/ 11/ rا.r. } \\
& \text { ثامناً: المجاميع القضائية }
\end{aligned}
$$

1. قضاء محكمة التمييز الاتحادية، قانون المرافعات المدنية، إعداد المحامي خليل إبراهيم المشاهدي، مطيعـة

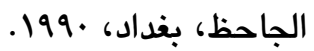


r. المبادئ القانونية في قضاء محكمة التمييز الاتحادية، المرافعات المدنية، إعداد القاضي لفتة هامل العجيلي،

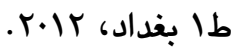

تاسعاً: المجلات الدورية

ا. النشرة القضائية تصدر عن مجلس القضاء الأعلى في العراق. r. المجموعة الأحكام العدلية تصدر عن وزارة العدل في جمهورية العراق. r. النشرة القانونية اعداد المحاميان داود سلمان الجنابي وياسم محمد الخفاجي.

ع. مجلة التشريع والقضاء تصدر عن لجنة دعم استقلال القضاء. 0. مجلة القضاء تصدرما نقابة المحاميين العراقيين. عاشراً: القوانين

1. القانون المدني رقم •ع لسنة 1901. r. ت قانون المرافعات المدنية رقم rی لسنة 1979 المعدل. r. قانون الإثبات رقم V.1 لسنة I9V9. حادي عشر: معاجم اللفة I. أبو الفضل جمال الدين محمد بن مكرم بن منظور الافريقي المصري، لسان العرب، طع، دار صادر للطباعة

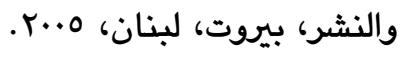

r. إسماعيل بن حماد الجوهري، معجم الصـحاح، قـاموس (عربي - عربـي)، طب، اعتنى بـه مـأمون خليـل

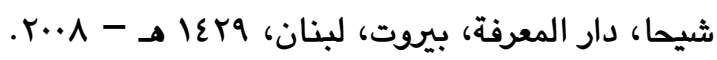

r. العلامة أبو القاسم الحسين بن محمد بن المفضل المعروف بالراغب الأصفهاني المتوفى سنة (r.0هـ) معجم

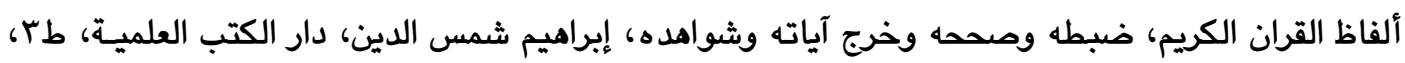

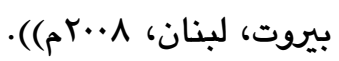

ع. العلامة الراغب الأصفهاني، مفردات ألفاظ القرآن الكريم، تحقيـق: صـفوان عـدنان داودي، منشـورات طليعـة

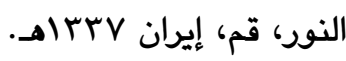

ه. أحمد بن محمد علي الفيومي المقري، المصباح المـير، المعجم، (عربـي - غربي) دار الحديث القـاهرة،

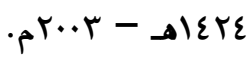

